\begin{abstract}
UNIVERSIDADE DE SÃO PAULO
FACULDADE DE FILOSOFIA, LETRAS E CIÊNCIAS HUMANAS DEPARTAMENTO DE LETRAS CLÁSSICAS E VERNÁCULAS PROGRAMA DE PÓS-GRADUAÇÃO EM FILOLOGIA E LÍNGUA PORTUGUESA
\end{abstract}

Lucienne Lautenschlager

A cidade maravilhosa no léxico de canções brasileiras compostas entre as décadas de 1930 e 1960.

VERSÃO CORRIGIDA

São Paulo

2015 


\section{A cidade maravilhosa no léxico de canções brasileiras compostas entre as décadas de 1930 e 1960.}

Dissertação apresentada ao Programa de PósGraduação em Filologia e Língua Portuguesa do Departamento de Letras Clássicas e Vernáculas da Faculdade de Filosofia, Letras e Ciências Humanas da Universidade de São Paulo para obtenção do título de Mestre em Letras.

Área de concentração: Filologia e Língua Portuguesa

Orientadora: Profa. Dra. Beatriz Daruj Gil

$$
\text { VERSÃO CORRIGIDA, }
$$

De acordo, 
Nome: LAUTENSCHLAGER, Lucienne

Título: A cidade maravilhosa no léxico de canções brasileiras compostas entre as décadas de 1930 e 1960.

Dissertação apresentada ao Programa de PósGraduação em Filologia e Língua Portuguesa do Departamento de Letras Clássicas e Vernáculas da Faculdade de Filosofia, Letras e Ciências Humanas da Universidade de São Paulo para obtenção do título de Mestre em Letras.

Aprovado em:

Banca Examinadora

Prof. Dr. Instituição:

Julgamento: Assinatura:

Prof. Dr. Instituição:

Julgamento: Assinatura:

Prof. Dr. Instituição:

Julgamento: Assinatura: 


\section{DEDICATÓRIA}

Aos meus pais, pela educação primeira, apoio, e por terem me ensinado a gostar de ler e estudar. 


\section{AGRADECIMENTOS}

À Prof. Dra. Beatriz Daruj Gil, meu especial agradecimento, pela dedicação, correção durante todo o processo de orientação e pela confiança depositada em mim, diante dos desafios propostos.

Ao Prof. Dr. Diósnio Machado Neto e à Prof. Dr. Maria Elizabeth Leuba Salum, que muito me ensinaram e contribuíram para meu crescimento científico e intelectual.

Aos meus pais, que me animaram, me ajudaram e me ensinaram, desde cedo, a importância e o gosto pelos estudos. À minha irmã, pelo exemplo de estudante e por ter me levado à USP pela primeira vez, me despertando a vontade quase obsessiva de nela poder estudar.

À minha chefe, Simone Stival, que tanto possibilitou este estudo.

Aos amigos Ana Tski, Diógenes Alvarenga, Edna Cruz, José Carlos Oliveira, Keyth Silva, Luiz Joari, Marcos Aurélio Pereira, Mônica Carvalho, Priscila Rizh, Ronaldo Novaes e Vera Petronzeli pelo carinho e apoio.

Às minhas melhores companhias, amigas-irmãs, Kátia Costa, Marjhorye Lucinger Ruiz e Nárjara Rodrigues e à madrinha, Selma Santos Carolino de Andrade, pelos incentivos constantes e ajuda em assuntos tanto pessoais como profissionais, permitindo a escrita desta dissertação.

Àqueles colegas de trabalho que me auxiliaram, durante as viagens profissionais, contribuindo com meus deslocamentos e estudos.

Ao Sr. Alberto Russi, responsável pela rádio e TV Univali e ao Sr. Alessandro Zans Isotton, programador sonoro, que me ajudaram na localização e disponibilização de algumas músicas. 
"Chega mais perto e contempla as palavras.

Cada uma tem mil faces secretas sob a face neutra".

Carlos Drummond de Andrade 


\section{RESUMO}

O objetivo desta pesquisa é analisar o léxico que enaltece a cidade do Rio de Janeiro, conhecida como cidade maravilhosa, em vinte e duas canções compostas entre as décadas de 1930 e 1960.

Parte-se do pressuposto de que os sentidos que cada palavra possui só são revelados quando estudados dentro de um determinado contexto, seja histórico, político, social e geográfico.

O léxico, quando atualizado no discurso, reflete o pensamento de um indivíduo ou de um grupo, que nada mais é do que a materialização da ideologia determinada pelos enunciadores ao fazerem suas escolhas lexicais. Ao optarem por essa ou aquela palavra, eles indicam suas crenças, valores e experiências acumuladas ao longo da vida.

Utilizam-se como bases teóricas para os estudos do léxico POTTIER (1972), VILELA (1979), BIDERMAN (2001) e VAN DIJK (1997; 2003; 2004; 2012; 2013) de modo a analisar as relações entre discurso, cognição, sociedade e contexto.

A partir disso é feita a organização das unidades lexicais - lexias - em campos semânticos para que se identifiquem subtemas relacionados à composição do tema "cidade maravilhosa".

Foram encontradas, nas letras das canções, temáticas relacionadas à figura feminina, à música, aos espaços urbanos e à cidade do Rio de Janeiro idealizada como a própria mulher. Os campos semânticos mostram que esses temas influenciaram a composição ideológica "cidade maravilhosa" e que, por meio da interface cognitiva, criaram a contextualização deste espaço brasileiro.

Palavras-chave: Análise crítica do discurso; Lexicologia; Cidade Maravilhosa; Rio de Janeiro 


\begin{abstract}
The objective of this research is to analyze the lexicon that emblazons Rio de Janeiro, known as "the wonderful city", through twenty-two songs written during the so-called "Golden age of radio".

To accomplish such task, one begins with the assumption that the sense each word has, reveals itself when studied within a given context, being it historical, political, social or geographical.

Lexicon, when applied in discourse, reflects individual or collective thought, which is nothing more than the materialization of the ideology that is determined by enunciators, once their lexical choices have been made. By selecting a word over another, beliefs, principles and lifetime experiences are conveyed.

This research has, as its theoretical basis, Pottier (1972) and Van Dijk (1997; 2003; $2004,2012)$ for the analysis of the relationship between discourse, cognition, society and context.

From this point forward, the lexical units are divided - lexias - into semantic fields to identify subthemes related to the larger theme "wonderful city".

Lastly, themes linked to women, music, urban spaces, and the notion of Rio de Janeiro being idealized as the woman itself are found in the lyrics of the songs in question. The semantic fields indicate that such themes have deeply influenced the ideological constitution of the term "wonderful city" and thus, through a cognitive interface, have shaped the contextualization of this Brazilian space.
\end{abstract}

Keywords: Critical discourse analysis; Lexicology; Wonderful city; Rio de Janeiro. 


\section{SUMÁRIO}

Introdução

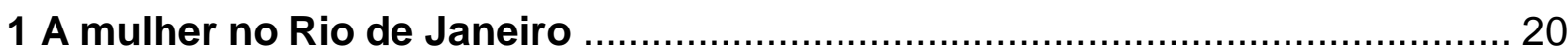

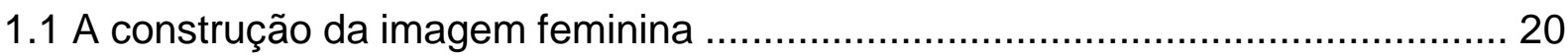

1.20 campo semântico "Mulher no Rio de Janeiro" .......................................... 22

$1.3 \bigcirc$ tratamento das lexias na caracterização da imagem feminina ...................... 25

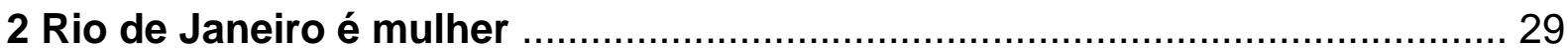

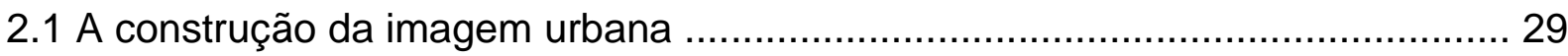

2.2 O campo semântico "Rio de Janeiro é mulher" ......................................... 30

$2.3 \bigcirc$ tratamento das lexias na caracterização da cidade ................................... 32

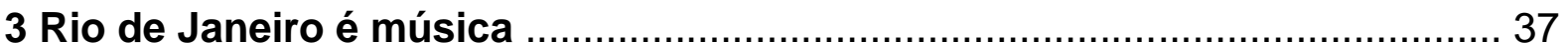

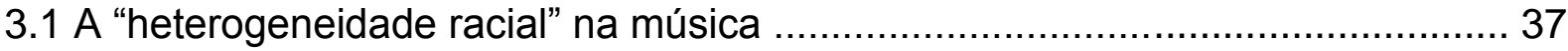

3.2 O campo semântico "Rio de Janeiro é música" ........................................... 40

$3.3 \bigcirc$ tratamento das lexias na caracterização musical ...................................... 41

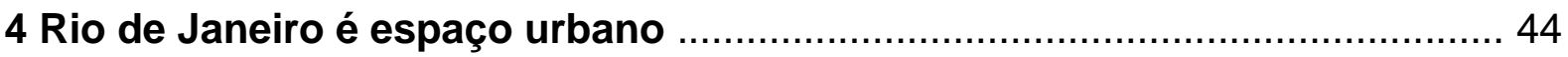

4.1 A visão urbana do espaço carioca ................................................... 44

4.2 O campo semântico "Rio de Janeiro é espaço urbano" ............................... 45

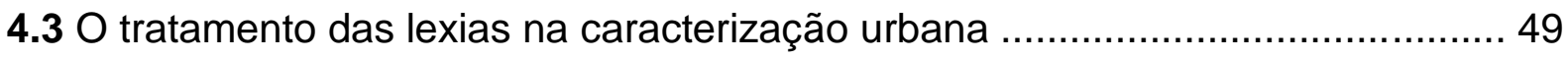

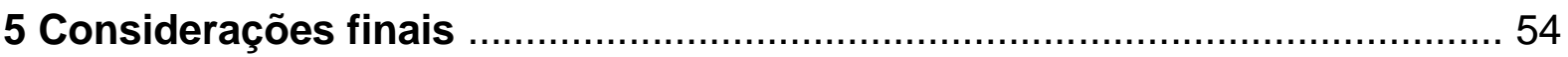


Referências

58

Anexo 1: Letras das canções analisadas

62 


\section{INTRODUÇÃO}

Conhecida como cidade maravilhosa, o Rio de Janeiro é muitas vezes sinônimo de Brasil. As praias, as mulheres, o clima e a beleza natural associados à cidade, eleita como Patrimônio Cultural da Humanidade pela UNESCO, servem de cenário a muitas novelas, clipes, desenhos, seriados e filmes nacionais e internacionais.

Abriga o Cristo Redentor, considerado a sétima maravilha mundial e o Pão de Açúcar - morro de formação rochosa com 396 metros de altura - que ajudaram a cidade a ser reconhecida inclusive no exterior com o seu aparecimento em novelas e filmes. O teleférico, que dá acesso a essa escultura, foi o terceiro a ser instalado no mundo e o primeiro no Brasil, o que ajudou a atrair os olhares para o espaço carioca.

Então capital federal, somado ao aparecimento na mídia, o Rio de Janeiro ganhou maior visibilidade e atraiu a atenção de toda a nação brasileira, no período pós-Proclamação da República, pois, pelo "fato de ter sido o novo regime proclamado por movimento que se desenrolara totalmente na capital" (CARVALHO, 1987, p. 16), as expectativas da população cresceram em relação à economia, à política e à cultura locais.

Pelo despertar destas expectativas, razões vinculadas à política e lutas sociais iniciadas, a cidade começou a receber uma exacerbada população de imigrantes - a maioria advinda de Portugal, bem como migrantes de várias regiões do Brasil, em sua maioria, formada por "ladrões, prostitutas, malandros, desertores do Exército, da Marinha e dos navios estrangeiros, ciganos, ambulantes, trapeiros, criados, serventes de repartições públicas, ratoeiros, recebedores de bondes, engraxates, carroceiros, floristas, bicheiros, (...) pivetes" (CARVALHO, 1987, p. 18). Como consequência desse crescimento populacional, a cidade passou a ser um verdadeiro espaço urbano marginalizado, cheio de conflitos de etnias e classes, nos quais contravenções, como desordem, vadiagem, embriaguez ou jogo, eram constantes. Surgiram também problemas com habitação (tanto em qualidade quanto em quantidade), abastecimento de água, saneamento e saúde, estes causadores da febre amarela, da varíola, da malária e da tuberculose.

À época, a cidade era foco das atenções de todo o país, não só por sua beleza natural ou por sua aparição na sétima arte, mas também pelo novo regime ter sido 
proclamado em terras cariocas e, posteriormente, pelos seus problemas sociais como confirma CARVALHO (1987, p. 22) ao sublinhar que "acontecimentos [na cidade do Rio de Janeiro], por banais que fossem, assumiam importância desmedida (...) pelo país inteiro".

Era preciso, portanto, "civilizar a antiga capital federal" (DINIZ, 2006, p. 24), não só em termos políticos e econômicos, mas também em termos culturais. A cidade necessitava de reformas em aspectos que envolviam tanto a higiene quanto a urbanidade. Os governantes, da época, cederam a um movimento elitista que considerou importante a retirada da pobreza e de todos os traços de africanidade dos centros, deslocando-os para as favelas e os subúrbios do Rio de Janeiro, então em franca constituição.

Paralelamente a essa política governamental surgiam novas tendências, novos gostos, lideranças intelectuais, culturais e políticas. Uma destas tendências foi o encontro dos sambistas em casas de mulheres baianas e festeiras, para celebrar, compor e interpretar a história da cultura negra do samba. Tia Ciata era uma destas mulheres, uma das mais notórias e importantes: cedia a casa para os encontros, dividindo-a do seguinte modo: "baile na sala de visita (choro), samba de partido-alto nos fundos da casa e batucada no terreiro (samba-de--umbigada)" (DINIZ, 2006).

Essa divisão era retrato de interação social, pois permitia que pessoas, de diferentes classes sociais, etnias e gêneros participassem de momentos de descontração, boemia, e muito além disso, de composição de canções com implicações não só estéticas, mas também ideológicas, a partir de um encontro de classes e grupos sociais heterogêneos: negros, mestiços, brancos, pobres e ricos. Assim, o samba nunca foi um gênero puro no sentido de estar desprovido de interferências ou misturas de ritmos, já que "as classes populares, sobretudo os 'negros pobres' do Rio de Janeiro" e mestiços do Nordeste [que migraram para lá] já tinham a sua leitura do mundo branco e da cultura hegemônica. (...) ela [a música urbana brasileira] já nasceu como resultado de um entrecruzamento de culturas" (NAPOLITANO, 2002, p. 48).

À medida que os grupos foram crescendo e as composições musicais aumentando, houve a necessidade de difundi-las. As pessoas, de modo geral, queriam conhecer e participar dessas experiências musicais, mesmo que só ouvindo, bebendo e se divertindo, reflexo de um crescimento urbano que demandava a criação 
de diferentes espaços de entretenimento e que fazia surgir teatros, salas de cinema, bares, entre outros.

Com o tempo, a tecnologia foi incorporada aos espaços de lazer. DINIZ (2006, p.16) destaca que "o telefone, o bonde elétrico e o automóvel encurtaram as distâncias e redimensionaram o olhar dos indivíduos sobre a cidade [do Rio de Janeiro]". Em 1920 , surgem os gramofones e o rádio, foi somente em 1930, no entanto, que este se consolidou como o meio de comunicação pelo qual pessoas, independentemente de gênero ou da classe social, conseguiam ter acesso às mesmas informações.

A primeira transmissão feita por rádio, no Brasil, aconteceu na cidade do Rio de Janeiro e, com isso, todas as experiências musicais acumuladas nessa cidade vão, de uma forma ou de outra, se fazer presentes no conhecimento de uma grande parcela da população, principalmente, daquela que já estava ávida pelo entretenimento (DINIZ, 2006, p. 18).

Já reconhecida nacional e internacionalmente, a cidade é saudada, em 1935, por André Filho, com a composição "Cidade Maravilhosa", cujo título se consagra como epíteto do local. A cidade maravilhosa "foi comentada, criticada e saudada por intermédio da música, seja com a alusão a suas ruas e seus bairros, seja por meio da crônica de seus personagens" MOUTINHO (2009, p. 17).

Para investigar as razões que justificam a perpetuação do epíteto "cidade maravilhosa", esta pesquisa pretende analisar o léxico que enaltece o Rio de Janeiro em vinte e duas canções ${ }^{1}$ brasileiras compostas entre as décadas de 1930 e 1960.

\footnotetext{
${ }^{1}$ As letras das canções encontram-se transcritas no anexo e as canções estão disponibilizadas em CD, também anexo.
} 


\begin{tabular}{|c|c|c|c|c|}
\hline & Canção & Compositor & Intérprete $^{2}$ & $\begin{array}{c}\text { Ano de } \\
\text { produção }\end{array}$ \\
\hline 1 & Cidade Maravilhosa & André Filho & $\begin{array}{c}\text { Aurora } \\
\text { Miranda e } \\
\text { André Filho }\end{array}$ & 1934 \\
\hline 2 & Feitiço da Vila & Noel Rosa & Noel Rosa & 1934 \\
\hline 3 & Cidade mulher & Noel Rosa & Orlando Silva & 1936 \\
\hline 4 & Pertinho do céu & $\begin{array}{l}\text { Wilson Batista e } \\
\text { Roberto Martins }\end{array}$ & Wilson Batista & 1941 \\
\hline 5 & Largo da Lapa & $\begin{array}{c}\text { Wilson Batista e } \\
\text { Marino Pinto }\end{array}$ & Wilson Batista & 1942 \\
\hline 6 & Rio & Ary Barroso & $\begin{array}{c}\text { Dircinha } \\
\text { Batista }\end{array}$ & 1948 \\
\hline 7 & Meu Rio de Janeiro & $\begin{array}{c}\text { Nelson Trigueiro e } \\
\text { Oscar Belandi }\end{array}$ & Dick Farney & 1948 \\
\hline 8 & Sábado em Copacabana & $\begin{array}{l}\text { Dorival Caymmi e } \\
\text { Carlos Guinle }\end{array}$ & $\begin{array}{l}\text { Dorival } \\
\text { Caymmi }\end{array}$ & 1951 \\
\hline 9 & Valsa de uma cidade & $\begin{array}{c}\text { Ismael Netto / Antônio } \\
\text { Maria }\end{array}$ & Os Cariocas & 1954 \\
\hline 10 & Tereza da Praia & $\begin{array}{l}\text { Tom Jobim e Billy } \\
\text { Blanco }\end{array}$ & $\begin{array}{c}\text { Dick Farney e } \\
\text { Lúcio Alves }\end{array}$ & 1954 \\
\hline 11 & Copacabana & Tom Jobim & Tom Jobim & 1954 \\
\hline 12 & Não vou pra Brasília & Billy Blanco & Os Cariocas & 1957 \\
\hline 13 & História da Lapa & $\begin{array}{c}\text { Wilson Batista e Jorge } \\
\text { de Castro }\end{array}$ & Wilson Batista & 1957 \\
\hline 14 & Corcovado & Tom Jobim & João Gilberto & 1960 \\
\hline 15 & Samba do avião & Tom Jobim & Os Cariocas & 1962 \\
\hline 16 & Ela é carioca & Tom Jobim & Tom Jobim & 1962 \\
\hline
\end{tabular}

${ }^{2}$ Os intérpretes foram escolhidos por serem os compositores ou por interpretarem a canção no mesmo ano de sua composição. 


\begin{tabular}{|c|l|c|c|c|}
\hline 17 & O morro não tem vez & $\begin{array}{r}\text { Tom Jobim / Vinícius } \\
\text { de Moraes }\end{array}$ & Tom Jobim & 1962 \\
\hline 18 & Rio & Ronaldo Bôscoli & Sylvia Telles & 1963 \\
\hline 19 & Mulher carioca & Vinícius de Moraes & $\begin{array}{c}\text { Vinícius de } \\
\text { Moraes }\end{array}$ & 1963 \\
\hline 20 & Garota de Ipanema & $\begin{array}{r}\text { Tom Jobim / Vinícius } \\
\text { de Moraes }\end{array}$ & Os Cariocas & 1963 \\
\hline 21 & Samba do carioca & $\begin{array}{c}\text { Vinícius de Moraes / } \\
\text { Carlos Lyra }\end{array}$ & Elis Regina & 1964 \\
\hline 22 & Rio 1800 & $\begin{array}{r}\text { Roberto Menescal e } \\
\text { Ronaldo Bôscoli }\end{array}$ & Os Cariocas & 1965 \\
\hline
\end{tabular}

Essas canções tematizam, direta ou indiretamente, o Rio de Janeiro. Parte delas (1 a 13) pertence ao período chamado Era de Ouro, que se iniciou na década de 1930 e chegou até meados dos anos 1950, época da ascensão do samba, da marchinha e do rádio. Outra parte das canções (14 a 22) integra o período de ascensão da televisão e da explosão musical em um Brasil ainda sob efeito da Era de Ouro.

Esta época é importante pois, até o rádio ser inventado, o samba caracterizavase por uma "fala cotidiana": a entoação, a expressão e a fala presentes em uma simples conversa de sambistas tornavam-se canções improvisadas, feitas a partir da combinação de melodia e letra, sem intenção de tornarem-se perenes (TATIT, 2004).

Depois de sua criação, a história do samba se modificou, fazendo surgir o que conhecemos hoje como canção popular. Os sambistas tiveram que trocar os improvisos e se afinar a uma noção estética para se adaptarem à fixação das melodias e ao registro das canções em discos (TATIT, 2004).

$\mathrm{Na}$ Era de Ouro, o rádio alcançou função integradora, pois, independentemente da classe social, da etnia, do gênero ou da idade, as pessoas tinham acesso às mesmas notícias, músicas e informações. Além disso, o teatro, até então frequentado por uma grande quantidade de indivíduos, perdeu público, porque muitos preferiam ouvir rádio a assistir aos espetáculos. 
O levantamento lexical das canções será organizado em campos semânticos, tendo como base os critérios e conceitos de lexia propostos por POTTIER (1978). campo semântico ou campo lexical - termo preferido por alguns autores - são "um paradigma lexical formado pela articulação e distribuição de um contínuo de conteúdo lexical por diversas unidades existentes na língua e que se opõem entre si por meio de simples traços de conteúdo" (VILELA, 1979, p. 60). É marcado por palavrastestemunha que são aquelas em torno das quais se organiza um conjunto de lexias, por aproximação semântica.

BIDERMAN (2001, p. 194) acrescenta que "os vocábulos componentes de um campo semântico registram numerosas mudanças de sentido, compondo um amplo leque de significados afins", de modo que se deve considerar a "heterogeneidade e a dinamicidade dos campos semânticos", que demandam atenção aos movimentos e às transformações da língua (NUNES, 2006, p. 156).

HENRIQUES (2001, p. 78, grifo do autor) utiliza a palavra "constelação" para descrever um campo semântico e explica que esse termo se refere "ao contingente de palavras que se agrupam, linguisticamente, por meio de uma rede de associações e interligações de sentido", as quais não possuem limite de quantidade.

As interligações de sentido podem ser feitas, de acordo com ULLMANN (1964, p. 133), com base em duas perspectivas: onomasiológica e semasiológica. A primeira "parte do sentido e procura identificar o nome, ou nomes" que estejam ligados a um termo estabelecido e a segunda "parte do nome e procura identificar significados". BIDERMAN (2001, p. 199) acrescenta que o campo onomasiológico "compreende todos os significantes (designações, nomes) de um dado significado", enquanto o campo semasiológico "compreende todos os significados possíveis que possam traduzir um determinado significante (nome)".

Para a composição do campo semântico utilizaremos a perspectiva onomasiológica, já que buscamos reunir conjuntos de lexias - unidades lexicais atualizadas no discurso - em forma de significados. HENRIQUES (2011) afirma que "lexias são unidades de características complexas cuja organização enunciativa é interdependente", o que significa que, de acordo com a necessidade discursiva, elas podem obedecer a diferentes combinações.

POTTIER (1978, p. 269) divide-as em quatro tipos:

a) lexia simples: "corresponde à palavra tradicional". Ex: "carioca". 
b) lexia composta: "é o resultado de uma integração semântica", e é reconhecida, sem dificuldade, por falantes de uma língua obedecendo a um padrão linguístico. Ex: "samba-canção".

c) lexia complexa: "é uma sequência [de palavras] em vias de lexicalização". Essas palavras correspondem a uma sequência já utilizada e reconhecida semanticamente dentro do discurso. Ex: "batida de bombo".

d) lexia textual: "é uma lexia complexa que alcança o nível de enunciado ou texto". Ex: "gosto de quem gosta desse céu, desse sol, dessa gente feliz".

BORBA (2003) atribui às lexias apenas duas classificações: simples e complexas. "São simples as lexias formadas por uma única forma livre e são complexas as que combinam mais de uma forma livre ou uma forma livre e uma ou mais de uma forma presa".

Para esse autor, as lexias complexas são intuitivas a um falante nativo. Para o falante estrangeiro, entretanto, não são tão facilmente captadas. Percebe-se que alguém domina uma língua quando consegue captar, apreender e entender uma lexia complexa.

BIDERMAN (2001), que também as divide em simples e complexas, concorda que nem sempre um linguista sabe ou consegue traçar os limites de uma lexia.

Embora POTTIER (1978) afirme que nenhum teste é suficiente, por si só, para determinar as lexias, é BIDERMAN (2001) que apresenta dois testes para detectar as lexias complexas: o primeiro é o teste da substituição, no qual, diante de uma sequência específica, podemos tentar trocar um dos vocábulos e tentar perceber se há um sentido lexicalizado, tanto para a sequência original quanto para a sequência trocada. Para ilustrar, observe a sequência "cidade maravilhosa" em comparação à "cidade admirável": a primeira combinação é uma forma reconhecida, de imediato, por muitos indivíduos, ao passo que o mesmo não acontece com a segunda combinação.

O próximo teste é o da inserção, que compreende a colocação de uma palavra no meio de alguma sequência identificada para perceber o grau de lexicalização que já existe, ou não, no conhecimento linguístico do usuário de uma determinada língua. Na mesma sequência "cidade maravilhosa", se acrescentarmos uma ou mais palavras nessa expressão, a naturalidade se esvazia. É o caso de "cidade de gente maravilhosa". Nota-se neste caso a perda na expressão de seu valor dentro da intuição ou do conhecimento do leitor, que deixa de pensar na cidade do Rio de 
Janeiro para imaginar uma outra cidade qualquer que tenha apresente esta característica.

É importante analisar o grau de coesão entre os constituintes da lexia complexa e o contexto no qual ela se encontra inserida, pois só desta forma é possível distinguir o que já está cristalizado na língua e o que ainda não está (BIDERMAN, 2001).

Soma-se aos tipos de lexias citados a discursiva, que é "um enunciado lexicalizado que compõe seu sentido em uma atualização discursiva única" (GIL, 2012, p. 9). É no discurso que as lexias se atualizam e revelam traços culturais, sociais e históricos. É nele que se "organizam as redes [ou os leques] de significados lexicais ou campos semânticos" (GIL, 2012, p. 7).

Após a definição dos campos semânticos, é possível analisá-los à luz da orientação sociocognitivista de VAN DJIK (2010), que propõe a inter-relação entre sociedade-cognição-discurso.

Para representar essa inter-relação, VAN DIJK (2003) define um triângulo, que aqui preferimos representar por um ângulo agudo - reunião de dois segmentos de reta orientados a partir de um ponto comum. Como pode-se representar um ângulo utilizando três letras - por exemplo $\mathrm{VAB}$ - consideraremos o $\mathrm{V}$, representando 0 vértice e, portanto, a cognição; a letra, $A$, como um ponto do primeiro segmento de reta representando o discurso e a letra, $B$, como representação de um ponto do segundo segmento de reta, denotando a sociedade:

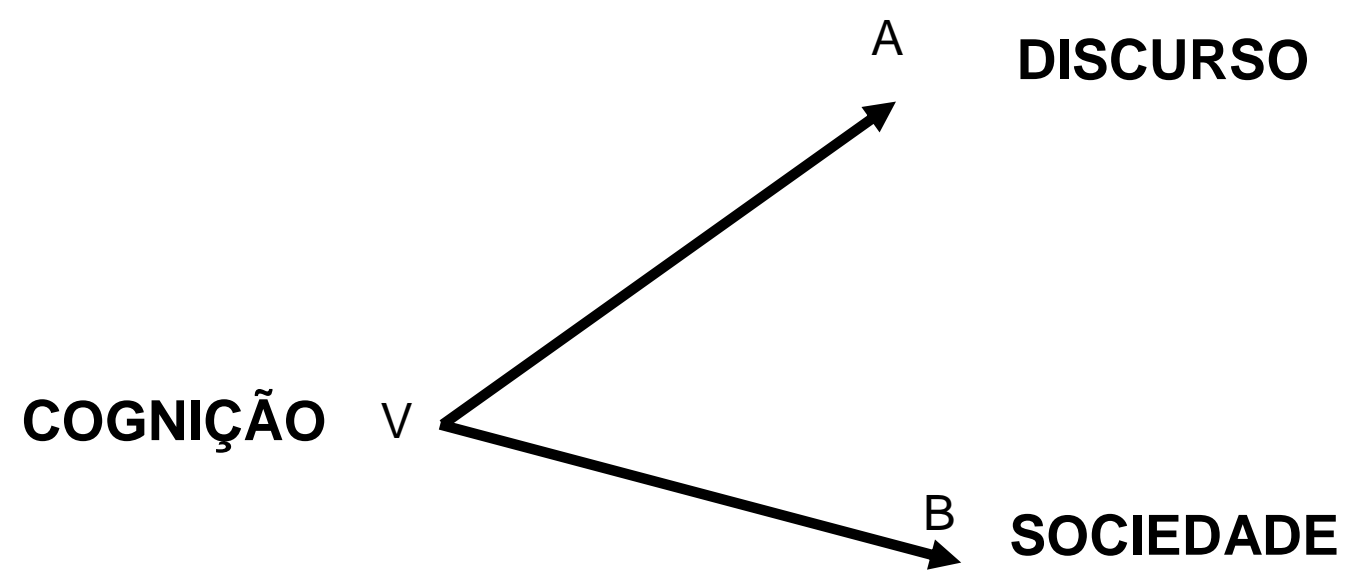

Figura 1: Relação discurso-cognição-sociedade, adaptada de VAN DIJK (2003) 
Nessa perspectiva, considera-se a cognição na posição angular; o discurso, em uma ponta; e a sociedade, na outra, pois não há relação entre os dois últimos elementos. Ambos estão relacionados por intermédio da cognição. Para o autor, não existe uma explicação social, sem pensar em aspectos cognitivos; e não há uma explicação da cognição, sem pensar em aspectos sociais.

O conceito de discurso explica que um texto, falado ou escrito, foi revelado de alguma forma por meio da língua. Entendido pelo viés cognitivo, ele passa a ser uma das principais condições mentais que os membros de uma sociedade linguística têm em comum. Assim, é preciso que o discurso seja influente ou convincente para que faça sentido na mente dos seus leitores. A cognição diz respeito aos modelos preestabelecidos já existentes na mente de um indivíduo que serão então utilizados nas mais diversas formas de interação/comunicação. Ela é aprendida, adquirida, formada e transformada tanto no nível individual quanto nas interações sociais. A sociedade compreende os mais diferentes grupos, instituições e organizações, em que haja interação coordenada e negociada entre os indivíduos. E, se há interação, haverá também compartilhamento de conhecimentos e crenças, o que é feito por meio do discurso.

O discurso possui um conjunto de propriedades, que podem ser o layout impresso de um texto, a base estrutural de um gênero discursivo, as estruturas retóricas, gramaticais ou as escolhas lexicais, entre outras. É com esta última propriedade que serão compostos nossos campos semânticos.

A cognição é organizada em dois tipos de memória: a episódica e a social. A primeira tem a ver com as crenças que adquirimos durante nossas experiências pessoais, a partir de eventos "vivenciados". A segunda é nosso conhecimento do mundo ou partilhado, que engloba não apenas o conhecimento social, mas também o histórico e o cultural.

A memória episódica tem como representação dois modelos mentais: o contextual e o de acontecimento. O primeiro é construído com base nas experiências que dão subsídios ao indivíduo para estabelecer crenças e pensamentos sobre um ato enunciativo. Essas crenças ou pensamentos tendem a variar de acordo com o contexto em que a pessoa está inserida. O segundo - de acontecimento - é uma espécie de modelo pronto sobre determinado tipo de interação. Permite uma interpretação do discurso à luz dos acontecimentos ou fatos de que se tem referência. 
Os modelos mentais podem, então, ser entendidos como "representações da realidade" e, como tais, influenciam nos julgamentos e opiniões dentro de eventos específicos, grupos e atores sociais.

As representações da realidade percebidas tanto por meio de experiências contextualizadas como por meio dos mais variados tipos de interação são mediadas pela cognição e construídas e divulgadas no discurso, que se materializa por meio da léxico-gramática. Para integrar a análise do léxico, a orientação sócio-cognitivista da análise crítica do discurso, pretende-se verificar, na construção dos campos semânticos, os modelos mentais que definem a construção discursiva.

Essa análise é apresentada nos próximos capítulos e é organizada da seguinte maneira: o primeiro capítulo, intitulado " $A$ Mulher no Rio de Janeiro", apresenta qual é a imagem que se constrói da mulher, advinda da cidade do Rio de Janeiro. O segundo capítulo, "Rio de Janeiro é Mulher", mostra a transposição da mulher sobre a cidade. O terceiro capítulo, "Rio de Janeiro é Música", tem como objetivo revelar a importância da música na construção do conceito "cidade maravilhosa" contribuindo com a ideia de alegria, entretenimento e, principalmente, a união inter-racial. O quarto capítulo intitula-se "Rio de Janeiro é espaço urbano" e discorre sobre locais públicos ou não; bairros e elementos naturais que aparecem como sinais de sentimentalismo ou de devoção voltados à cidade do Rio de Janeiro.

Nas "Considerações finais" descreveremos a visão da "cidade maravilhosa" que se revela no discurso, por meio das canções, a partir das escolhas lexicais que foram efetuadas por seus autores. Em seguida, apresentam-se as "Referências" e, por último, os "Anexos", nos quais apresentaremos as letras das canções selecionadas. 


\section{A mulher no Rio de Janeiro}

\subsection{A construção da imagem feminina}

As canções do corpus constroem um sujeito romântico, sensível e encantador. TINHORÃO (1997) reforça o binômio lírico amor/flor como temática principal em muitas composições musicais, feitas em meados da década de 1950. A sensibilidade, a sabedoria, por diversas vezes, tomam conta das letras dessas composições, que, por vezes, adentraram o cenário musical como "a música brasileira carregada de excelência e beleza". (CASTRO, 1948)

NAPOLITANO (2002) sublinha que a formação de uma imagem poética nessas canções era constante. Essa imagem é apontada por DINIZ (2006), quando afirma serem as escolas de samba as grandes responsáveis pela síntese de muitos movimentos carnavalescos, os quais se resumem em: enredo, carros alegóricos, alas, instrumentação, mestre-sala e porta-estandarte e, principalmente, mulher e beleza, todos voltados ao conjunto revelado nos desfiles das escolas de samba.

No caminho entre os instantes da "excelência e beleza" e da "imagem poética", RIDENTI (2000, p. 55) descortina o "romantismo revolucionário", que surge nas canções compostas após o ano de 1960 como sendo a valorização do passado e a busca pelas raízes a fim de contribuir com uma transformação no futuro. A arte seria, então, um meio de propagação de valores e "sínteses modernas de (...) romantismo". Nessa mesma época, ocorre um "movimento de jovens da Zona Sul carioca que cantam o amor, o sol, o mar e [novamente] a beleza da mulher" (DINIZ, 2006, p. 130, grifo nosso).

Se a construção poética e romântica é completamente ideológica, no sentido de "ser um conjunto de acepções, ideias, representações, teorias que se orientam para a estabilização, ou legitimação, ou reprodução, da ordem estabelecida" (LÖWI, 2008, p. 12), podemos dizer que são práticas discursivas. As ideologias da beleza feminina não são envolvidas apenas na produção e na compreensão das letras das canções ou verificadas nas escolas de samba como mero romantismo, beleza ou 
poesia, mas, sim, consideradas como práticas discursivas, pelas quais se torna observável uma ideologia. É pelo discurso que ideias são expressas, formuladas e reproduzidas.

Essa formulação não se dá apenas na composição musical, uma vez que os compositores não são levados, sem motivo algum, a escreverem com um léxico determinado, mas, sim, o fazem a partir de uma interface cognitiva entre determinada situação e um discurso ou texto, o que diz respeito ao modelo mental que eles têm sobre a feminilidade (VAN DIJK, 2003).

Esses modelos mentais definem as visões sociais" de mundo, que compreendem todos aqueles "conjuntos estruturados de valores, representações, ideias e orientações cognitivas" (LÖWI, 2008, p. 13). Desse modo, os modelos mentais podem ser chamados de contextos (VAN DIJK, 2012).

Os contextos são definidos com base nas definições subjetivas dos compositores e controlam todos os aspectos de produção e compreensão do discurso. Nesse caso, considera-se a visão social que se tem da mulher construída e divulgada a partir de escolhas lexicais específicas.

A observação dessas escolhas se configura como uma técnica que objetiva investigar a maneira como as formas linguísticas funcionam na reprodução, manutenção e transformação social. Esses contextos evidenciam crenças sociais e não opiniões individuais.

Assim sendo, a construção da imagem feminina pode influenciar muitas atitudes sociais, sejam elas masculinas ou femininas, infantis ou adultas. Isto porque, entendida como uma ideologia, ela atua na estrutura global dos modelos mentais, os quais podem ser facilmente inferidos, adquiridos e distribuídos de acordo com o grupo social, no qual o indivíduo encontra-se inserido.

Como afirma MELO (2012) os analistas críticos do discurso estão centrados na análise da reprodução de doutrinas que sustentam certas ideologias por meio do discurso, atuando na legitimação do poder, na manipulação do consentimento, no papel da política ou da mídia ou na produção discursiva da relação de dominação entre grupos. Ainda segundo o autor, são essas preocupações que distinguem a análise crítica do discurso dos outros tipos de análise.

A principal função no levantamento da construção da imagem feminina, sua influência social e sua possível presença em modelos mentais repousa no conceito de sujeito ou ator social, que é aquele que ao mesmo tempo que sofre uma 
determinação linguística, trabalha sobre as estruturas mentais, podendo ou não modificá-las.

Essa determinação linguística, apesar de ser precisa pela cognição, sofre influências em todas interações discursivas. As estruturas - tanto linguísticas como cognitivas - estão em constante risco material devido às práticas cotidianas.

Nas canções analisadas, a estrutura linguística que reforça a percepção e a interpretação de uma imagem feminina se mantém ao longo das práticas discursivas, representando informações embasadas no cotidiano dos enunciadores que expressam modelos mentais reais. Cria-se, então, o primeiro campo semântico.

\subsection{0 campo semântico "Mulher no Rio de Janeiro"}

O campo semântico "Mulher no Rio de Janeiro" organiza lexias que contribuem para a constituição do sentido que os enunciadores têm a respeito da relação entre a cidade do Rio de Janeiro e a mulher.

A cada escolha lexical, a imagem do feminino se organiza, se reorganiza, se atualiza e se amplia no discurso de acordo com o projeto de expressão de ideias do enunciador. 


\begin{tabular}{|c|c|c|c|}
\hline \multicolumn{4}{|c|}{ Quadro 1: Campo semântico MULHER NO RIO DE JANEIRO } \\
\hline & Lexias $^{3}$ & Classificação & $\begin{array}{c}\mathbf{N}^{\circ} \text { de } \\
\text { ocorrências }\end{array}$ \\
\hline \multicolumn{4}{|c|}{ Subcampo 1.1: Traços físicos femininos } \\
\hline 1 & cabelo castanho & composta & 1 \\
\hline 2 & cabrocha faceira & complexa & 1 \\
\hline 3 & cabrochas gingando seus quadris & textual & 1 \\
\hline 4 & corpo & simples & 1 \\
\hline 5 & ela & simples & 11 \\
\hline 6 & ela tem um passinho & textual & 1 \\
\hline 7 & laiá & simples & 1 \\
\hline 8 & jeitinho & simples & 6 \\
\hline 9 & louras & simples & 1 \\
\hline 10 & luz do seu olhar & textual & 1 \\
\hline 11 & menina & simples & 1 \\
\hline 12 & moça do corpo dourado & textual & 1 \\
\hline 13 & morena(s) & simples & 4 \\
\hline 14 & nariz levantado & complexa & 1 \\
\hline 15 & nua & simples & 1 \\
\hline 16 & olhos verdinhos & complexa & 1 \\
\hline 17 & pinta do lado & complexa & 1 \\
\hline 18 & sereias & simples & 1 \\
\hline 19 & seu balançado & complexa & 1 \\
\hline 20 & Sinhá & simples & 1 \\
\hline 21 & sorriso de mulher & complexa & 2 \\
\hline 22 & tamanco na ladeira & complexa & 1 \\
\hline 23 & tem tanta coisa que nem sabe que tem & textual & 1 \\
\hline 24 & tem um jeitinho de nhem-nhem-nhem & textual & 1 \\
\hline 25 & tem um pouquinho que ninguém tem & textual & 1 \\
\hline 26 & Tereza da praia & complexa & 3 \\
\hline
\end{tabular}

${ }^{3} \mathrm{~A}$ escolha da ordem de apresentação das lexias representa subcampos, organizados em ordem alfabética. 


\begin{tabular}{|c|c|c|c|}
\hline \multicolumn{4}{|c|}{ Subcampo 1.2: Adjetivos pátrios } \\
\hline 27 & amazonense & simples & 1 \\
\hline 28 & baiana & simples & 1 \\
\hline 29 & capixaba & simples & 1 \\
\hline 30 & carioca & simples & 5 \\
\hline 31 & cearense & simples & 1 \\
\hline 32 & gaúcha & simples & 1 \\
\hline 33 & mineira & simples & 1 \\
\hline 34 & nordestina & simples & 1 \\
\hline 35 & paulista & simples & 1 \\
\hline 36 & pernambucana & simples & 1 \\
\hline \multicolumn{4}{|c|}{ Subcampo 1.3: Sedução feminina } \\
\hline 37 & $\begin{array}{l}\text { a beleza que existe/ a beleza que não é só } \\
\text { minha }\end{array}$ & textual & 1 \\
\hline 38 & amar & simples & 4 \\
\hline 39 & amor & simples & 4 \\
\hline 40 & amor de pequena & complexa & 1 \\
\hline 41 & $\begin{array}{l}\text { ao encontrar você, eu conheci/ o que é a } \\
\text { felicidade }\end{array}$ & textual & 1 \\
\hline 42 & apagar da velha chama & textual & 1 \\
\hline 43 & bela & simples & 1 \\
\hline 44 & beleza triste & complexa & 1 \\
\hline 45 & carinho & simples & 4 \\
\hline 46 & cheia de graça & complexa & 1 \\
\hline 47 & coisa mais linda & complexa & 2 \\
\hline 48 & $\begin{array}{l}\text { cuidando do teu benzinho/ que também vai te } \\
\text { cuidar }\end{array}$ & textual & 1 \\
\hline 49 & doçura & simples & 1 \\
\hline 50 & é de dar água na boca & textual & 1 \\
\hline 51 & eu esperei por essa noite & textual & 1 \\
\hline 52 & fazer feliz a quem se ama & textual & 1 \\
\hline 53 & graças que tem & textual & 1 \\
\hline
\end{tabular}




\begin{tabular}{|l|l|c|c|}
\hline 54 & ilusão & simples & 1 \\
\hline 55 & linda & simples & 2 \\
\hline 56 & mais feliz que eu & textual & 1 \\
\hline 57 & meu amor & complexa & 4 \\
\hline 58 & morrendo de saudade & complexa & 1 \\
\hline 59 & mulher(es) & simples & 4 \\
\hline 60 & na base do sozinho não dá pé/ nunca vai dar & textual & 1 \\
\hline 61 & novo amor & complexa & 3 \\
\hline 62 & o mundo inteirinho se enche de graça/ e fica & textual & 1 \\
\hline 63 & mais lindo/ por causa do amor & textual & 1 \\
\hline 64 & poema & simples & 3 \\
\hline 65 & por que estou tão sozinho? & textual & 1 \\
\hline 66 & querer-bem & composta & 1 \\
\hline 67 & quero a vida sempre assim/ com você perto & textual & 1 \\
\hline 68 & triste mim & simples & 2 \\
\hline 69 & tudo quanto eu amei & textual & 2 \\
\hline
\end{tabular}

\subsection{O tratamento das lexias na caracterização da imagem feminina}

Do total de sessenta e nove lexias que compõem o campo semântico "Mulher no Rio de Janeiro", observa-se que as vinte e seis primeiras constroem a imagem de mulher ou de mulheres, demarcando características peculiares ao universo feminino e esculpindo um ser humano com perfeição de traços (feição) e de sentimentos, já que há preocupação em feminizar desde a face até os quadris. 
Essas lexias exaltam a "moça do corpo dourado" (12)4, a "morena" (13) e o "cabelo castanho" (1) mais que as "louras" (9). Organizam a face da mulher discriminando os "olhos verdinhos" (16), a "luz do seu olhar" (10), um "nariz levantado" (14), um "sorriso de mulher" (21) com uma "pinta do lado" (17). Comprovam que FREYRE (2003, p. 72), discursivamente, também estava certo ao afirmar que

(...) o nosso lirismo amoroso não revela outra tendência senão a glorificação da mulata, da cabocla, da morena celebrada pela beleza dos seus olhos, pela alvura de seus dentes, pelos seus dengues, quindins e embelegos muito mais do que as "virgens pálidas" e as "louras donzelas".

Além de construírem um rosto feminino, essas lexias referenciam, diretamente, a mulher, tanto pela utilização do pronome "ela" (5) - que verificado onze vezes possui o maior número de ocorrências neste campo - quanto pelo uso do substantivo próprio "Tereza da praia" (26) ou dos substantivos femininos "menina" (11), "cabrocha faceira" (2), "laiá5 (7)" e "Sinhá6 (20)".

Em relação à lexia "corpo" (4), observa-se alusão à estrutura física com as "cabrochas gingando seus quadris" (3), "seu balançado" (19), e "ela tem um passinho" (6) que pode ser revelado com um "tamanco na ladeira" (22), mostrando todo um "jeitinho" (8) sensualizado de ser. Essa referência é ampliada com a utilização das lexias simples "sereias" (18) e "nua" (15). Nelas, a qualidade corporal é o substancial. Não se pretende criar a imagem de um corpo qualquer e sim um que atenda às sociedades contemporâneas, onde o culto ao corpo é intensificado, a cada dia, por meio de imposições estéticas socialmente vigentes.

Há uma preocupação em privilegiar uma beleza perfeita e uma vaidade excessiva, ligada, por exemplo, ao rebolado das mulheres e à lexia "sereia" (18), a qual já aciona um modelo mental de acontecimento, que retoma um ser mitológico metade peixe, metade mulher, que esbanja luxúria e perfeição.

Isso "é de dar água na boca" (50) ao enunciador, que ao encontrar uma "mulher" (59) conhece o que é a felicidade (41) e por isso deseja que ela o acompanhe até o

\footnotetext{
${ }^{4}$ Sempre que mencionarmos as lexias, elas estarão referenciadas pelo seu número indicador, presente na primeira coluna, ao lado esquerdo, da tabela.

${ }^{5}$ De acordo com o dicionário Aurélio, laiá era o tratamento dado às meninas e às moças no tempo da escravidão.

${ }^{6}$ De acordo com o mesmo dicionário, Sinhá era o tratamento que os escravos davam às senhoras, nesse mesmo tempo.
} 
"apagar da velha chama” (42). Nessa canção (Corcovado, 1960), há a nítida configuração da imagem da cidade do Rio de Janeiro como sinônimo de paz e tranquilidade, tornando-a por isso, um excelente lugar para se viver grandes amores.

A cidade é o espaço onde é possível comprovar as "graças que tem" (53) a figura feminina, que de tão bela (43) pode ser comparada a um "poema" (64). Toda essa sensualidade está ligada, portanto, à ideia da meiguice. Forma-se, aos poucos, a imagem de uma mulher sensível, graciosa e irresistível. São trinta e três as lexias (37 a 69) que compõem esta visão, ou seja, quase metade do campo semântico é ocupado com o assunto.

Nesse subgrupamento, o romantismo é diretamente ligado à feminilidade, e a mulher que aparece no léxico das canções é aquela expressa em um caráter de amor misturado às muitas doses d'“a beleza que existe" (37), que, de acordo com os enunciadores, não é só deles podendo, portanto, ser de todas as pessoas que passam pelas mulheres e que podem contemplá-las.

A postura feminina é marcada por lexias como "amor de pequena" (40), "doçura" (49), "cheia de graça" (46); demonstra-se a importância de a mulher "fazer feliz a quem se ama" (52) e "ir cuidando de um benzinho/ que também vai cuidar [dela]" (48), isto porque o enunciador evidencia que "na base do sozinho não dá pé/ nunca vai dar" (60). Desta maneira, a seleção lexical deixa emblemática a mulher amorosa, que deve "amar" (38) e ter (um) "amor" (39).

Estas duas últimas lexias - "amar" (38) e "amor" (39) - possuem o mesmo número de ocorrências: quatro, além de outras lexias que fazem alusão ao sentimento, como "carinho" (45), "meu amor" (57), "novo amor" (61) ou "o mundo inteirinho se enche de graça/ e fica mais lindo/ por causa do amor" (62).

Seja amando ou deixando-se amar, a mulher vai assumindo uma postura de dedicação e de grande cuidado ao homem. O amor passa a ser visto como um sentimento passivo, em que a mulher assume o papel principal de [novamente] "fazer feliz a quem se ama" (52). É a mulher que tem que se manter "cheia de graça" (46) e "linda" (55) para manter o companheiro apaixonado, pois este não quer se sentir privado desse sentimento.

A solidão, aliás, é por vezes trazida à tona pelo enunciador: "por que estou tão sozinho?" (65) ou comentada - conforme já explicitado - "na base do sozinho não dá pé/ nunca vai dar" (60); "quero a vida sempre assim/ com você perto de mim" (67), o que pode manter relação com as lexias "triste" (68), "morrendo de saudades" (58) 
"ilusão" (54) e "tudo quanto eu amei" (69), o que significa que ficar impedido de amar é sinônimo de infelicidade ou de uma "beleza triste" (44). Por isso, o enunciador prefere "esperar por uma noite" (51) em que ele possa encontrar uma mulher que seja a "coisa mais linda" (47) a quem possa "querer bem" (66).

As demais lexias desse campo, apresentadas entre os números 27 e 36 , reúnem as mais diferentes regionalidades que as mulheres podem assumir: "amazonense" (27), "baiana" (28), "capixaba" (29), "carioca" (30), "cearense" (31), "gaúcha" (32), "mineira” (33), "nordestina” (34), "paulista” (35) e "pernambucana" (36). Destaca-se a "carioca" (30) por ter cinco ocorrências e pelo contexto (Mulher Carioca, 1963), no qual é ela e somente ela que "tem tanta coisa que nem sabe que tem" (23). É a carioca que "tem um jeitinho de nhem-nhem-nhem" (24) e "um pouquinho que ninguém tem" (25), como mostra a canção Mulher Carioca, 1963.

Do ponto de vista cognitivo, essas escolhas lexicais descrevem um modelo mental contextual de mulher: o que o enunciador imagina que seu interlocutor pensa sobre mulher, o que o enunciador imagina sobre o julgamento que seu interlocutor faz sobre sua visão de mulher que, nesse caso, parece ser a "bela" (43) e a vaidosa. Também temos evidenciados os modelos de acontecimento, que é a visão de uma mulher dedicada, que ama e que, por isso, pode ser considerada como responsável (cuidadora) do seu companheiro. Ficar desacompanhado implica em deixar uma pessoa que tem alguém "mais feliz que o enunciador" (56) e mesmo que a "paixão não o aniquile" (63) ele precisa se sentir acolhido mesmo que seja pela Vila Isabel, bairro pertencente à cidade do Rio de Janeiro (Feitiço da Vila, 1934). 


\section{Rio de Janeiro é mulher}

\subsection{A construção da imagem urbana}

Os estudos sobre a mulher no léxico das canções não se esgotam na construção da imagem poética ou da figura feminina, mas se ampliam para a visão de que a cidade do Rio de Janeiro pode ser a própria mulher.

Fonte de inspiração, a mulher revela modelos mentais, os quais são estruturas cognitivas que operam representações subjetivas, mas operacionais, da sociedade, pois, apesar de serem entendidos como valorações ou como atribuições de juízo de valor em uma determinada situação, são eles que iniciam o processo de construção de sentido. Só é possível compreender os discursos, a partir do momento que somos capazes de construir modelos mentais sobre eles.

Nessa contextualização para a construção da cidade maravilhosa, duas relações podem ser definidas: a da cidade do Rio de Janeiro com 0 gênero feminino e, paralelamente, a do aspecto cognitivo com a sociedade. À medida que pensamentos, emoções e representações da memória vão sendo revelados por meio das escolhas lexicais, o discurso toma forma e retorna à cognição para, através dela, revelar o que está sendo relevante e reproduzido na sociedade.

Assim, quando a mulher aparece sendo a própria urbe, os discursos são interpretados como coerentes, em relação aos modelos mentais que os enunciadores têm sobre os acontecimentos referentes ao nosso primeiro campo semântico (Mulher no Rio de Janeiro). Ele forma a base para a produção e compreensão da urbanidade.

Forma-se a partir desse caso uma ideia de que a cidade contém a mulher e de que a mulher contém a cidade. Desta forma, o que o enunciador lembra em relação à cidade, não é necessariamente o seu significado, mas o modelo mental construído durante a compreensão deste espaço. As representações socialmente partilhadas são expressas em lexias e revelam 
as interpretações que os enunciadores fizeram das mulheres, dentro de um local específico.

Ao se observar essa construção imagética, podemos construir um modelo único da mulher ou atualizar um modelo antigo. Qualquer que seja a opção, não podemos nos afastar de nossa base referencial local (a cidade do Rio de Janeiro), as circunstâncias paisagísticas e as características humanas emprestadas.

Considera-se portanto a representação da mulher a construção da imagem poética feminina e a cidade do Rio de Janeiro (tomada por balanço e sentimentos) como aspectos sociais constituídos, já que os compositores das músicas, por serem usuários da língua, representam a sociedade de modo autêntico.

\subsection{0 campo semântico "Rio de Janeiro é mulher"}

O campo semântico "Rio de Janeiro é mulher" organiza lexias que contribuem para a transposição que os enunciadores fazem da cidade do Rio de Janeiro para a mulher.

As trinta e uma ocorrências lexicais encontradas nas canções estão organizadas na tabela abaixo, na coluna do lado esquerdo e se destacam por serem elementos do contexto linguístico e estarem centradas em aspectos femininos materializados na própria cidade do Rio de Janeiro. 


\begin{tabular}{|c|c|c|c|}
\hline \multicolumn{4}{|c|}{ Quadro 2: Campo semântico RIO DE JANEIRO É MULHER } \\
\hline & Lexias $^{7}$ & Classificação & $\begin{array}{c}\mathrm{N}^{\circ} \mathrm{de} \\
\text { ocorrências }\end{array}$ \\
\hline \multicolumn{4}{|c|}{ Subcampo 2.1: Sentimentos } \\
\hline 1 & beijar & simples & 1 \\
\hline 2 & e o amor, estava em tudo que eu vi & textual & 1 \\
\hline 3 & é tanto amor/ fazendo o Rio assim & textual & 1 \\
\hline 4 & $\begin{array}{l}\text { encantando nossos olhos/ prende o } \\
\text { nosso coração }\end{array}$ & textual & 1 \\
\hline 5 & eterno se fazer amar & textual & 1 \\
\hline 6 & joia rara & composta & 1 \\
\hline 7 & meu Rio da mulher beleza & textual & 1 \\
\hline 8 & perdido de amor & complexa & 1 \\
\hline 9 & Rio de Janeiro, gosto de você & textual & 1 \\
\hline 10 & Rio, eu gosto de você & textual & 1 \\
\hline 11 & Rio, você foi feito pra mim & textual & 1 \\
\hline 12 & saudade & simples & 1 \\
\hline 13 & sorrio pro meu Rio & textual & 1 \\
\hline \multicolumn{4}{|c|}{ Subcampo 2.2: Personificação } \\
\hline 14 & beijos do sol e abraços do mar & textual & 1 \\
\hline 15 & cheia de encantos mil & complexa & 1 \\
\hline 16 & cidade de amor & complexa & 1 \\
\hline 17 & cidade inimitável & complexa & 1 \\
\hline 18 & cidade irresistível & complexa & 1 \\
\hline 19 & cidade mais bela & complexa & 1 \\
\hline 20 & cidade maravilhosa & composta & 1 \\
\hline 21 & cidade mulher & complexa & 1 \\
\hline 22 & cidade notável & complexa & 1 \\
\hline 23 & cidade que ninguém resiste & textual & 1 \\
\hline 24 & cidade sensível & complexa & 1 \\
\hline 25 & encanto que tu possuis & textual & 1 \\
\hline
\end{tabular}

${ }^{7}$ A escolha da ordem de apresentação das lexias representa subgrupos, organizados em ordem alfabética. 


\begin{tabular}{|c|l|c|c|}
\hline 26 & Rio amando & complexa & 1 \\
\hline 27 & Rio que balança & complexa & 1 \\
\hline 28 & Rio que sorri de tudo & textual & 1 \\
\hline 29 & sempre sorrindo & complexa & 1 \\
\hline 30 & terra de amor & complexa & 1 \\
\hline 31 & terra que a todos seduz & textual & 1 \\
\hline
\end{tabular}

\subsection{O tratamento das lexias na caracterização da cidade}

Como poderemos observar, o amor, a paixão e o carinho retratados nas canções aparecem ora voltados para o Rio de Janeiro, ora voltados para as mulheres. Os enunciadores favorecem uma mescla desses referentes, causando certa confusão no leitor ou ouvinte em relação a entender se o amor evidenciado está voltado para a cidade maravilhosa ou para uma amada real ou imaginária.

Pode-se analisar que essa mescla é proposital e essencial para que se crie uma percepção da figura feminina como a dos próprios espaços urbanos. A cidade que emerge no pensamento do receptor passa a ter um panorama figurativo e a emoção transparece por meio de um sentimentalismo declarado. Sobre isso, VAN DIJK (2012, p. 23) declara que
emoções são temporais, contextuais e pessoais, psicologicamente baseadas em eventos interpretados cognitivamente. (...) Portanto, uma vez que ideologias são compartilhadas socialmente, elas não podem, por definição, ser "emocionais". Entretanto, seus usos ou aplicações por membros individuais de grupos em situações concretas podem desencadear e serem expressos como emoções. Também por essa razão é essencial distinguir analiticamente as ideologias e seus usos atuais ou manifestações no discurso (...).

Sendo as letras das canções uma situação concreta em que se manifesta o discurso, é possível distinguir, por meio de análise da escolha 
lexical, uma expressão emocional compartilhada socialmente, mas que deve ser entendida cognitivamente.

Assim sendo, a emoção do enunciador é validada à medida que ele demonstra uma paixão muito mais pelo que ele quer que a cidade seja, do que pelo ela realmente é, haja vista que as lexias desse campo podem ser distinguidas tanto pelo seu teor personalizado quanto pelo teor sentimental. Seja por um ou pelo outro, a cidade descrita nunca é vista pela sua parte física, fria ou concreta, e sim caracterizada, constantemente, com características femininas emocionais ou calorosas.

Para que possamos apresentar as categorias supracitadas podemos observar as lexias de 1 a 13 deste campo semântico, nomeado como "Rio de Janeiro é mulher", as quais serão chamadas de "emocionais", pelo fato de retratarem um sentimentalismo e de estarem enviesadas a uma cidade, que nesse momento, também é sentimental. As lexias numeradas de 14 a 31 serão reconhecidas como "personificação", por conferirem à cidade do Rio de Janeiro características humanas e, também, femininas.

O subcampo de lexias que remete ao que estamos chamando aqui de "emocionais" denota uma exorbitância de sentimentos. Quase nada os supera, somente a vontade de amar, beijar (1) ou sorrir do poeta, que transforma o léxico em mensagens de dedicação absoluta à cidade do Rio de Janeiro como: "Rio de Janeiro, gosto de você" (9), "eterno se fazer amar" (5), "sorrio pro meu Rio" (13), "e o amor, estava em tudo que eu vi" (2). É mister ficar "perdido de amor" (8) e sentir "saudade" (12) de uma cidade que é uma "joia rara" (6), envolta por "tanto amor, fazendo o Rio assim" (3) "meu Rio da mulher beleza" (7).

Procura-se associar ao Rio conceitos como "cidade inimitável" (17), "cidade mais bela" (19) e "cidade notável" (22) pelo "encanto que tu [Rio de Janeiro] possuis" (25). A cidade passa a gozar de uma autoridade emocional que, por ser natural, não pode jamais ser contestada e sim sentida, admirada, apreciada e cantada.

Em relação ao subcampo da "personificação", temos uma imagem bastante homogênea da mulher sobreposta à cidade no que diz respeito à sensualidade, à alegria e à afetuosidade, como, por exemplo, em "cheia de encantos mil" (15), "encantando nossos olhos, prende o nosso coração" (4), 
"Rio que balança" (27), "Rio que sorri de tudo" (28), "sempre sorrindo" (29), "Rio amando" (26), "beijos do sol e abraços do mar" (14), "terra de amor" (30).

Há, então, a construção de uma "cidade mulher" (21) que ama, que se dedica e que encanta. A cidade é "irresistível" (18), assim como a mulher que chama a atenção por onde ela passa por ser vaidosa. A cidade do Rio de Janeiro passa a ser a "cuidadora" das pessoas que nela habitam ou que a visitam, já que é "terra de amor" (30) e "terra que a todos seduz" (31). A sedução é o principal recurso para fazer da capital do Rio de Janeiro "a cidade que ninguém resiste" (23).

Mais uma vez não se tem a imagem de uma mulher que é feia ou executiva, mas sim uma mulher fascinante, vista através do espaço urbano carioca. Isso tudo é construído progressivamente de uma lexia a outra ao se utilizarem referências como o encantamento (cheia de encantos mil (15) ou encantando nossos olhos (4)), a sedução (cidade sensível (24) ou cidade irresistível (18)) e o ato de balançar (Rio que balança - 27). Com esse último termo, cria-se uma ambiguidade proposital e, com ela, uma sobreposição da ideia do balançar os quadris com o balançar das ondas do mar.

A alegria é marcada pelo ato de sorrir provocado pela própria cidade do Rio de Janeiro e a afetuosidade é revelada pelos "beijos do sol e abraços do mar" (14), numa "cidade de amor" (16), "que ninguém resiste" (23) porque as pessoas sempre estão "amando" (26).

É possível observar que as lexias apresentadas nesse grupo ressaltam apenas características positivas e, na maioria das vezes, ligadas ao sexo feminino, para quem ouve o enunciador falar sobre o Rio de Janeiro. Ele revela um quê de sentimentalismo em todas as ocorrências determinadas na tabela e, quando afirma "Rio, eu gosto de você" (10) e "Rio, você foi feito pra mim" (11), contribui na construção da imagem do Rio como "cidade maravilhosa" (20), amada e desejada por todos. A cidade torna-se a mulher que todos desejam e a que veneram.

Assim como no primeiro campo semântico em que a mulher é marcada pelo sentimentalismo e romantismo, aqui o Rio de Janeiro se aproveita dessas características e as amplia para além do ser humano, a fim de alcançar paisagens ou até mesmo espaços físicos cariocas.

Associadas aos sistemas de cognição, essas lexias fazem com que 0 ouvinte ou leitor compreenda e se sinta pertencente ao sentimentalismo 
proposto pelas condições idealizadas do enunciador. As afirmações acima são conectadas e incorporadas socialmente por meio do discurso. Isso acontece porque, segundo VAN DIJK (2004), nesse discurso encontram-se condições, tais como:

1. O enunciador sabe que a cidade do Rio de Janeiro pode ser comparada à mulher.

2. O enunciador acredita que a cidade do Rio de Janeiro seja uma mulher.

3. O enunciador quer que a cidade do Rio de Janeiro seja uma mulher.

4. O enunciador considera bom que a cidade do Rio de Janeiro seja confundida com uma mulher.

Um elo importante que observamos aqui é que os modelos mentais, criados a partir dessas condições, sobre o território da cidade podem ser derivados de abstração, generalização ou contextualização. Assim, se ouvirmos regularmente, nas canções, sobre a maravilha e a delícia de se morar no Rio de Janeiro e suas características femininas, aprenderemos, pouco a pouco, que essa cidade pode assumir, no entendimento do indivíduo, o papel de esposa ou de uma figura feminina importante em sua vida. Logo, ele pode morar, passear ou, simplesmente, ter afeição especial pela cidade, sem se dar conta que isso se encontra de forma arbitrária em seu modelo mental.

Dessa forma, passaremos a acreditar no quanto a cidade do Rio de Janeiro pode ser comparada a uma mulher, desejar que o seja e considerar esta uma ideia benéfica. Estando em harmonia com o pensamento do enunciador, há a possibilidade desta crença servir de base a discursos futuros.

"Uma comunicação verdadeira envolve conhecimento real, crenças e desejos" (VAN DIJK, 2004). Ao transpor essa sedução, esse sentimento e essa feminilidade nas lexias, o enunciador quer que os sentimentos sejam interiorizados pelo leitor ou ouvinte, porque acredita positivamente neles e espera que eles sejam reconhecidos por meio do discurso. 
Apesar de MÁXIMO (2009, p. 28), afirmar que por mais cariocas que sejam, no clima, na bossa, na gente que retrata, as canções [voltadas ao Rio] têm mais jeito de cantos de amor à musa do que ao lugar", há controvérsias, pois observamos no campo semântico "Rio de Janeiro é mulher" que a verdadeira musa da canção é a própria cidade personificação do Rio de Janeiro.

CABRAL (2009, p. 51) afirma que a cidade do Rio de Janeiro foi cantada nos sambas e nas marchas e que a principal exaltação aparece na canção Cidade mulher (1936), de Noel Rosa, na qual há "todos os objetivos a que [a cidade] tinha direito".

Isto é facilmente observado nas lexias 16 a 24 que a tratam por "cidade irresistível" (18), "cidade sensível" (24), ou "cidade de amor" (16), características humanas que se tornam femininas e, portanto, personificadas, quando relacionadas à lexia "cidade mulher" (21).

Todas as referências, criadas por Noel, têm como fim a expressão macro "cidade maravilhosa" (20), que também pode marcar uma personificação, já que, segundo uma das definições presentes no dicionário Aurélio, maravilhoso(a) significa "pessoa ou coisa admirável, extraordinária". Se o Rio de Janeiro, assim como qualquer outra cidade, não pode ser visto como uma "coisa", iremos, consequentemente, considerá-lo como uma "pessoa" que, de acordo com as lexias, seria uma mulher.

Finalmente, a organização do léxico nos dois campos semânticos já analisados contextualiza o sexo feminino, o sentimentalismo e a personificação, evidenciando que não existe "cidade maravilhosa" sem mulher, ou, mesmo, como a mulher em si. 


\section{Rio de Janeiro é música}

\subsection{A heterogeneidade racial na música}

A música é lugar de identidade e alteridade: revela temas, assegura uma identidade histórica no interior da canção, retrata épocas, povos e regiões. Denota que todo tema musical possui uma porção maior ou menor de singularidade, que necessita ser completada com a presença do "outro", em maior ou menor proporção (TATIT, 2002).

Investigar as lexias que constroem uma ideologia musical advinda do Rio de Janeiro é, antes de tudo, fazer analogia com a história da cidade que se liga num grau indeterminado de retroação - inclusive por alteridade - entre o universal e o "local da cultura". Deve-se observar o entrelaçamento do léxico, o qual serve de suporte para a análise das canções. Isso significa penetrar a essência do discurso que nem sempre está presente no que se narra, mas, sim, no local de onde se narra (MACHADO NETO, 2012).

E é perceptível que, nas canções aqui analisadas, o local de onde se narra é marcado claramente pelas seguintes lexias: "Rio de Janeiro", "cidade maravilhosa". Não importa a denotação ou a conotação, pois o local é marcado de modo profícuo e específico nas canções.

Identificado o local descrito, pode-se retirar das obras a identidade histórica carioca. Caracterizado como "usina musical", o Rio de Janeiro pode ser considerado "o ponto de encontro de materiais e estilos musicais diversos, além de sediar boa parte das agências econômicas responsáveis pela formatação e distribuição do produto musical" (NAPOLITANO, 2002, p. 39). Esse encontro contribuiu com a propagação interclassista, inter-racial e interregional.

Tudo isso é ponto positivo ao Rio de Janeiro, que em decorrência da intensa imigração e do rápido crescimento populacional, era palco de convivência entre pessoas das mais variadas classes, etnias e sociedades. 
Tomando a ideia de FREYRE (2003), que vê as mais variadas formas de integração, a interdependência e a comunicação recíproca entre diferentes culturas, grupos, gêneros ou classes como uma manifestação da organização populacional brasileira, vemos no Rio um espelho dessa miscigenação e dessa coexistência, por vezes, conflituosa e, por outras, cheia de harmonia.

Esse lado harmonioso se deu pelo samba e pelo carnaval, tanto que DINIZ (2006) revela que eram nas festas, aos finais de semana, que conviviam os tambores brutos, os choros, o maxixe e o samba, transformando o Rio de Janeiro no principal ambiente de encontro das classes sociais.

Nessa mesma época, que data de meados do século XIX, existiam as casas das mulheres baianas e festeiras, onde os sambistas eram acolhidos para festejarem, comporem e interpretarem a história da cultura negra do samba. A casa da tia Ciata, já citada como uma das mais famosas e importantes, era frequentada por negros, mestiços e brancos, pobres e ricos, sem distinção de classe, gênero ou etnia.

Essa indistinção revela um "caráter que tomou a colonização do Brasil, a formação sui generis da sociedade brasileira, (...), ainda hoje sobre antagonismos" (FREYRE, 2003, p. 69).

Segundo $o$ autor, a base da sociedade brasileira foi formada a partir da relação entre brancos e negros, brancos e índios, negros e índios. Em decorrência disto, o Brasil revelou-se um país mulato e o povo brasileiro passou a se ver como resultado de uma fusão harmoniosa entre etnias e culturas.

DINIZ (2006, p. 34) afirma que

(...) na década de 20 , os negros e mestiços eram considerados um grande empecilho para o desenvolvimento econômico e social do país. A partir das últimas décadas do século XIX, teorias racistas pregavam a vinda de imigrantes europeus para acelerar o embranquecimento da sociedade. Só depois da publicação de Casa Grande e Senzala, do pernambucano Gilberto Freyre, na década de 30, a nossa hibridez étnica começou a ser motivo de "orgulho nacional".

A "heterogeneidade racial" era uma característica tanto das festas de samba quanto das festas de carnaval. Deste ponto em diante, a tecnologia começou a se desenvolver e a improvisação a se limitar, tanto que TATIT (2004, p. 97) declara que "a institucionalização do carnaval como maior festa popular 
e a consolidação do rádio como primeiro veículo de massa" aconteceram em meados da década de 1930, o que contribuiu com o abastecimento aos rádios de canções por meio dos principais compositores da época - o que justifica, mais uma vez, a escolha das músicas neste trabalho, datadas dessa época, delineando também a linguagem da canção popular brasileira, a qual passava a ser menos improvisada e menos falada.

NAPOLITANO (2002) explica que a tradição musical brasileira acabou por ter que acompanhar as dinâmicas da modernização do país ao adentrar um circuito comercial e comunicacional e amplia esta ideia com a aceitação de que alguns grupos sociais, como os negros e os mestiços, desenvolveram estratégias de inserção, nessa tradição musical, ritualizando tanto formas musicais quanto coreografias.

No discurso, isso aparece quando analisamos as lexias que se referem às batidas, aos instrumentos relacionados ao samba ou à música pois, para um compositor, escrever uma música é uma experiência rotineira que se junta a outras experiências da vida pessoal ou profissional como ler livros e jornais, fazer ligações telefônicas, falar com colegas, participar de entrevistas. Muitas dessas atividades envolvem a prática discursiva, o que faz com que muitas canções sejam resultado de todo um processo de informações extraídas de diferentes fontes sociais.

A experiência compositora é, portanto, uma sequência contínua de práticas discursivas, de modo que qualquer compositor já tem à sua disposição modelos mentais contextuais sobre o tema principal escolhido para canção (VAN DJIK, 2012). 
3.20 campo semântico "Rio de Janeiro é música"

O campo semântico "Rio de Janeiro é música" organiza trinta e uma lexias que refletem instrumentos e gêneros musicais.

Quadro 3: Campo semântico RIO DE JANEIRO É MÚSICA

\begin{tabular}{|l|l|c|c|}
\hline \multicolumn{2}{|c|}{ Lexias } & Classificação & $\begin{array}{c}\mathbf{n}^{\circ} \text { de } \\
\text { ocorrências }\end{array}$ \\
\hline \multicolumn{2}{|l|}{ Subcampo 3.1: A música no Rio de Janeiro } \\
\hline 1 & abram alas pro morro & textual & 1 \\
\hline 2 & berço do samba & complexa & 1 \\
\hline 3 & bossa que faz temperado do céu & textual & 1 \\
\hline 4 & canta, Rio & complexa & 1 \\
\hline 5 & $\begin{array}{l}\text { o morro não tem vez/ se derem vez ao } \\
\text { morro/ toda cidade vai cantar }\end{array}$ & textual & 1 \\
\hline 6 & $\begin{array}{l}\text { Rio tu és de janeiro/ és sempre o } \\
\text { primeiro num samba-canção }\end{array}$ & textual & 1 \\
\hline 7 & valsa de uma cidade & complexa & 1 \\
\hline \multicolumn{3}{|l|}{} \\
\hline Subcampo 3.2: Tríade cantar-sambar-dançar & \multicolumn{2}{|c|}{} \\
\hline 8 & a morena vai sambar & textual & 1 \\
\hline 9 & canção & simples & 1 \\
\hline 10 & canta & simples & 2 \\
\hline 11 & cantam alegremente & textual & 1 \\
\hline 12 & cantar & simples & 1 \\
\hline 13 & dançar & simples & 2 \\
\hline 14 & lindas canções & complexa & 1 \\
\hline 15 & minha alma canta & 9 \\
\hline 16 & não tem medo de bamba & 1 \\
\hline 17 & samba & \\
\hline
\end{tabular}




\begin{tabular}{|c|l|c|c|}
\hline 18 & samba-canção & composta & 1 \\
\hline 19 & sambar & simples & 1 \\
\hline 20 & serestas lindas & complexa & 1 \\
\hline \multicolumn{3}{|l|}{} \\
\hline \multicolumn{3}{|l|}{ Subcampo 3.3: Balanço e batuque } & simples \\
\hline 21 & balançar & simples & 2 \\
\hline 22 & balanço & complexa & 1 \\
\hline 23 & baticum lelê & complexa & 1 \\
\hline 24 & batida de bombo & simples & 1 \\
\hline 25 & batucada & simples & 1 \\
\hline 26 & batucar & complexa & 1 \\
\hline 27 & batuque do bom & simples & 2 \\
\hline 28 & pandeiro & simples & 2 \\
\hline 29 & tamborim & simples & 1 \\
\hline 30 & vibra & simples & 1 \\
\hline 31 & violão & & 1 \\
\hline
\end{tabular}

\subsection{O tratamento das lexias na caracterização musical}

Constata-se que, neste campo semântico, as lexias fazem referência à música, como, por exemplo, instrumentos ou gêneros. Além disso, há ainda a presença da cidade do Rio de Janeiro associada à música, como podemos observar nas lexias numeradas de 1 a 7.

Nelas se vê a cidade do Rio de Janeiro sendo explicitada em "canta, Rio" (4), "valsa de uma cidade" (7). Em "Rio tu és de janeiro/ és sempre o primeiro num samba-canção" (6), a escolha lexical provoca uma ambiguidade que remete à ideia de "campeão", pois, ao utilizar as lexias janeiro e primeiro, temos contida a ideia de que janeiro é o primeiro mês do ano e, se a cidade do Rio é "de janeiro", ela só pode ser primeira num samba-canção, logo, ela 
pode ser a campeã em alegria, em beleza ou em natureza, conforme já mostraram os campos semânticos anteriores.

O conceito de "campeã" possui uma relação com o carnaval e com as escolas de samba, já que, ao final do desfile, há a apuração de votos para se eleger a escola que merece destaque. Assim, temos a lexia "abram alas pro morro" (1), que transforma o acidente geográfico em uma espécie de agremiação, e que, como tal, deseja aparecer, se revelar e lembrar o Rio como o "berço do samba" (2), em que pessoas "cantam alegremente" (11) "lindas canções" (14).

Com a ação de cantar constrói-se a tríade cantar-sambar-dançar, presente na tabela nas lexias de 8 a 20. Destaca-se nesse grupo a lexia "samba" (17) com nove ocorrências, a qual não por acaso, nasceu na cidade do Rio de Janeiro. Se a julgarmos como representação de uma categoria musical compartilhada por várias etnias, gêneros e classes, fruto de uma base cultural miscigenada, teremos uma interpretação, não imediata, mas muito significativa, de um evento que comunica um Rio de Janeiro maravilhoso por conviver com antagonismos de todas as ordens harmonicamente.

Soma-se a isso "a morena vai sambar" (8), que dialoga com o campo semântico "Rio é mulher". Associa-se o samba à morena, que é uma figura recorrente da cidade do Rio de Janeiro.

Nas lexias de 21 a 31, há a presença de instrumentos, balanço e batuque. O cenário musical é reforçado pelos instrumentos musicais "pandeiro" (28), "tamborim" (29), "batida de bombo" (24) e "violão" (31) - e pela representação do batuque - "batucada" (25), "batuque do bom" (27) - , entre outras lexias.

A natureza aparece mais uma vez no campo semântico por meio da lexia "bossa que faz temperado do céu" (3), mostrando que até a bossa se mistura ao céu da cidade, que, como visto anteriormente, é azul e constelado.

A paisagem denuncia uma situação social na lexia de número 5 - "o morro não tem vez/ se derem vez ao morro/ toda cidade vai cantar" - pois ela revela por meio de seu contexto a difícil vida no morro, que, talvez pela existência dos cortiços, pela dificuldade de se ter um emprego ou uma vida digna, clama por "ter vez" e fazer a "cidade cantar". Ainda assim, não podemos ignorar a presença de um aspecto geográfico que faz parte da natureza e da identidade da cidade. 
Pode-se comprovar esse discurso por meio de DINIZ (2006), ao sublinhar que os morros eram limitados do ponto de vista de moradia e técnico-musical, mas que se destacavam pela inventiva poética das pessoas que ali moravam, em que favela e morro se associavam emblematicamente no universo do surgimento do samba.

SILVA (1999) explora as favelas dos morros como um bom exemplo de incorporação da geografia urbana, o que significa, que ainda hoje, eles "não têm vez". São submetidos à intervenção do homem, modificando sua identidade desde o ano de 1920, quando começaram a ser suprimidas pelo crescimento urbano, fazendo as pessoas que ali moravam buscarem novas formas de sobrevivência. Mesmo assim, a cidade do Rio "não tem medo de bamba"8 (16) e apesar do desenvolvimento urbano trazer algumas dificuldades ou interferir em problemas sociais, mais uma vez todos "cantam alegremente" (11) "serestas lindas" (20). Afinal, a ordem é "canta, Rio" (4).

8 De acordo com o dicionário Aurélio, bamba significa indivíduo que domina um assunto. 


\section{Rio de Janeiro é espaço urbano}

\subsection{A visão urbana do espaço carioca}

Um espaço, segundo SILVA (1999), pode ser pensado a partir das relações sociais nele instauradas. O Rio de Janeiro é um território que se desenvolveu com "altos índices de população marginal e de imigração, o desequilíbrio entre os sexos, a baixa nupcialidade, a alta taxa de nascimentos ilegítimos" (CARVALHO, 1987, p. 27).

Havia na cidade, devido à quantidade de imigrantes que lá foram viver, a presença de diferentes gêneros, culturas e etnias, o que fez com que o espaço territorial da cidade abrigasse diversas categorias sociais, uma dentro do outra ou várias em um local só. SILVA (1999, p. 57) exemplifica que um simples espaço como o da Candelária - igreja localizada no centro da cidade do Rio de Janeiro e um dos principais monumentos históricos da cidade pode ser visto de vários ângulos, pois contém vários "sistemas cognitivos". Assim, a igreja pode ser percebida tanto como um "espaço urbano que é utilizado pelo pessoal do mercado financeiro que percebe a rua apenas como uma via de acesso", o que lhe dá a possibilidade de ser mera via de acesso, um meio que liga dois pontos, quanto de ser transformada, literalmente, em "ponto final dos meninos de ruas".

As diversas leituras que se fazem de uma mesma cidade dependem do "reconhecimento da multiplicidade de processos sociais no espaço urbano" (SILVA, 1999, p. 57) que formam um contexto e refletem no discurso das "situações sociais" geradas a partir das interpretações (inter)subjetivas dos participantes. Essa interpretação é fundada em um processo cognitivo que controla os processos da produção discursiva (VAN DJIK, 2012).

Quando encontramos nas canções a visão "maravilhosa” dos espaços, é possível considerar a interpretação do indivíduo que é subjetiva e se interrelaciona com outras interpretações de outros atores e que, nas canções 
analisadas enaltece "o jardim florido" e o "céu azul" aos "altos índices de população marginal e de imigração", por exemplo. Isso significa que a visão do espaço carioca é sempre explicitada como uma cidade extraordinária ou surpreendente, ainda que LOPES (2009) aponte a cidade como problemática, no auge dos seus 400 anos. À época - por volta dos anos 1950 -, o autor descreve os momentos infelizes advindos de fatos como seu passado de sede de capitania, seu retalho em sesmaria, freguesias e circunscrições, os constantes alagamentos decorrentes de enchentes e a perda da invejada condição de capital da República.

MÁXIMO (2009) observa que muitas são as canções que retratam diferentes espaços do Rio de Janeiro. Das favelas à emergente Zona Sul, dos morros aos exemplos típicos de "bairrismo", a cidade maravilhosa está lá nas canções, de um jeito ou de outro, com qualidades ou com defeitos, mas sempre com um tom de beleza ou com menções que "descortinam a dor e a delícia" de viver neste lugar.

Isso reforça a dimensão que a cidade toma diante das pessoas que lá viviam e que compunham as canções. Elas têm um modelo mental relacionado à "cidade maravilhosa" e, por isso, revelam no discurso a natureza ou um espaço visto de um ângulo sempre belo e especial.

\subsection{O campo semântico "Rio de Janeiro é espaço urbano"}

O campo semântico "Rio de Janeiro é espaço urbano" organiza lexias que refletem traços do pensamento dos enunciadores em relação à cidade do Rio de Janeiro e aos locais constituintes dessa cidade.

Este campo semântico compreende o maior campo de nossa pesquisa, apresentando um total de oitenta e seis lexias. 


\begin{tabular}{|c|c|c|c|}
\hline \multicolumn{4}{|c|}{ Quadro 4: Campo semântico RIO É ESPAÇO URBANO } \\
\hline & Lexias & Classificação & $\begin{array}{c}\mathbf{N}^{\circ} \text { de } \\
\text { ocorrências }\end{array}$ \\
\hline \multicolumn{4}{|c|}{ Subcampo 4.1: Valores culturais } \\
\hline 1 & a beleza do meu país & textual & 1 \\
\hline 2 & $\begin{array}{l}\text { a vila tem um feitiço sem farofa/ sem } \\
\text { vela/ sem vintém que nos faz bem }\end{array}$ & textual & 1 \\
\hline 3 & aonde eu fui criado & textual & 1 \\
\hline 4 & cidade do sonho e grandeza & textual & 1 \\
\hline 5 & desafio quem prove o contrário & textual & 1 \\
\hline 6 & $\begin{array}{l}\text { eu caio duro, mas fico em } \\
\text { Copacabana }\end{array}$ & textual & 1 \\
\hline 7 & foi na Lapa que eu aprendi a ler & textual & 1 \\
\hline 8 & $\begin{array}{l}\text { gosto de quem gosta desse céu, } \\
\text { desse sol, dessa gente feliz }\end{array}$ & textual & 1 \\
\hline 9 & joia da terra brasileira & textual & 1 \\
\hline 10 & me criei feliz & textual & 1 \\
\hline 11 & na Lapa, eu quero morrer & textual & 1 \\
\hline 12 & $\begin{array}{l}\text { Rio,tu és de janeiro e do ano inteiro, } \\
\text { quem há de negar? }\end{array}$ & textual & 1 \\
\hline 13 & se derem vez ao morro & textual & 1 \\
\hline 14 & sempre há beleza & textual & 1 \\
\hline 15 & só a ti Copacabana/ eu hei de amar & textual & 1 \\
\hline 16 & um bom lugar & textual & 1 \\
\hline \multicolumn{4}{|c|}{ Subcampo 4.2: Lugares } \\
\hline 17 & bar & simples & 2 \\
\hline 18 & bate-papo de café & textual & 1 \\
\hline 19 & beira-mar & composta & 1 \\
\hline 20 & calçada cheia de gente a passar & textual & 1 \\
\hline 21 & caminho do mar & complexa & 1 \\
\hline 22 & Corcovado & simples & 1 \\
\hline 23 & Cristo Redentor & composta & 2 \\
\hline 24 & da janela vê-se o Corcovado & textual & 1 \\
\hline
\end{tabular}




\begin{tabular}{|c|c|c|c|}
\hline 25 & Galeão & simples & 1 \\
\hline 26 & Guanabara & simples & 2 \\
\hline 27 & igreja & simples & 1 \\
\hline 28 & Ilha de Paquetá & composta & 1 \\
\hline 29 & Pão de Açúcar & composta & 1 \\
\hline 30 & Quinto Distrito & composta & 1 \\
\hline 31 & Rio & simples & 1 \\
\hline 32 & vejo o Rio de Janeiro & textual & 1 \\
\hline \multicolumn{4}{|c|}{ Subcampo 4.3: Bairros cariocas } \\
\hline 33 & Copacabana & simples & 6 \\
\hline 34 & Copacabana, feiticeira & textual & 1 \\
\hline 35 & Copacabana, princesinha do mar & textual & 1 \\
\hline 36 & Ipanema & simples & 1 \\
\hline 37 & Lapa & simples & 3 \\
\hline 38 & Lapa boêmia & complexa & 1 \\
\hline 39 & Lapa vadia & complexa & 1 \\
\hline 40 & Lapa, dos capoeiras & complexa & 1 \\
\hline 41 & Leblon & simples & 1 \\
\hline 42 & nome de princesa & complexa & 1 \\
\hline 43 & Santa Tereza & complexa & 1 \\
\hline 44 & Vila Isabel & complexa & 1 \\
\hline \multicolumn{4}{|c|}{ Subcampo 4.4: Paisagem natural } \\
\hline 45 & águas verdes & complexa & 1 \\
\hline 46 & ar brilhando & complexa & 1 \\
\hline 47 & arvoredo & simples & 1 \\
\hline 48 & azul & simples & 2 \\
\hline 49 & céu & simples & 6 \\
\hline 50 & cidade de flores & complexa & 1 \\
\hline 51 & cidade do céu sempre azulado & textual & 1 \\
\hline 52 & cidade padrão de beleza & textual & 1 \\
\hline 53 & clima é bem tropical & textual & 1 \\
\hline 54 & clima é bom & textual & 1 \\
\hline
\end{tabular}




\begin{tabular}{|c|c|c|c|}
\hline 55 & constelado & simples & 1 \\
\hline 56 & dourado quase todo dia & textual & 1 \\
\hline 57 & é sal, é sul & textual & 1 \\
\hline 58 & foi a natureza quem te protegeu & textual & 1 \\
\hline 59 & jardim florido & complexa & 1 \\
\hline 60 & jardins de sol & complexa & 1 \\
\hline 61 & lua & simples & 2 \\
\hline 62 & manhãs & simples & 1 \\
\hline 63 & mar & simples & 5 \\
\hline 64 & meu Rio é lua & textual & 1 \\
\hline 65 & mil verões & complexa & 1 \\
\hline 66 & morro & simples & 5 \\
\hline 67 & noite & simples & 2 \\
\hline 68 & noites do Rio ao luar & textual & 1 \\
\hline 69 & o morro quer se mostrar & textual & 1 \\
\hline 70 & olha a pista chegando & textual & 1 \\
\hline 71 & praias & simples & 4 \\
\hline 72 & $\begin{array}{l}\text { quem mora em Santa Tereza/ está } \\
\text { pertinho do céu }\end{array}$ & textual & 1 \\
\hline 73 & raiar & simples & 2 \\
\hline 74 & Rio de sol, de céu, de mar & textual & 1 \\
\hline 75 & Rio é mar & complexa & 1 \\
\hline 76 & Rio que mora no mar & textual & 1 \\
\hline 77 & Rio, teu mar, praias sem fim & textual & 1 \\
\hline 78 & serra de veludo & complexa & 1 \\
\hline 79 & sol & simples & 7 \\
\hline 80 & sol a queimar & complexa & 1 \\
\hline 81 & sol da Vila & complexa & 1 \\
\hline 82 & tardes quentes & complexa & 1 \\
\hline 83 & tardinha & simples & 1 \\
\hline 84 & terra & simples & 2 \\
\hline 85 & vento & simples & 1 \\
\hline 86 & verdes montanhas & complexa & 1 \\
\hline
\end{tabular}




\subsection{O tratamento das lexias na caracterização urbana}

Observa-se que o campo semântico "Rio de Janeiro é espaço urbano" possui uma rede de significação que valida a cidade do Rio de Janeiro como um espaço envolto pelos mais diferentes sentimentos e emoções, os quais contêm um traço semântico de devoção ao solo, às tradições, à defesa da beleza e à integridade. Este traço pode ser encontrado nas lexias de 1 a 16, como "a beleza do meu país" (1), "cidade de sonho e grandeza" (4), "só a ti Copacabana eu hei de amar" (14). Há nestas expressões a ideia de que o Rio é a cidade mais bela de todo o país e que, por possibilitar o nascer dos sonhos, é um lugar onde há muitas esperanças e gratidão.

O Rio, enquanto cidade natal, desperta no indivíduo a vontade de explicitar o carinho e o reconhecimento por se ter nascido naquele espaço. $O$ enunciador materializa no discurso essa gratidão e a opinião de que, mesmo com problemas sociais, não deixaria o local por nenhum outro.

Há um bairrismo que evidencia um enunciador voltado à sua cidade, a sua terra ou até mesmo ao seu bairro. Exemplo disto são as lexias "gosto de quem gosta desse céu, desse sol, dessa gente feliz" (8), "eu caio duro, mas fico em Copacabana" (6) e "desafio quem prove o contrário" (5).

Na primeira lexia - "gosto de quem gosta desse céu, desse sol, dessa gente feliz" (8), o enunciador afirma gostar de quem gosta de elementos naturais trazidos pela cidade e, com isso, nega gostar de quem não compartilha a mesma opinião que ele sobre o céu, o sol e da gente feliz que vive ali. A segunda - "eu caio duro, mas fico em Copacabana" (6) - mostra a construção da ideia de que "nem morto" deixaria um bairro da cidade do Rio de Janeiro e, na última - "desafio quem prove o contrário" (5) -, as pessoas que não são cariocas ou que não compartilham da ideia de que o Rio tem motivos para ser maravilhoso são provocadas pelo autor da letra da canção a provar o contrário.

Em uma cidade que possui "clima bem tropical" (53), céu "constelado" (54) e que não é "apenas do mês de janeiro", mas, sim, do "ano inteiro" (12), 
o enunciador procura dificultar o discurso de alguém que quisesse argumentar contrariamente esse espaço.

Ao perguntar quem há de negar e desafiar o ouvinte a provar 0 contrário, o autor gera por meio do discurso uma verdade irrevogável a partir da concretização emocional, feita com base em um modelo mental pessoal e subjetivo.

Sobre isso, VAN DIJK (2012, p. 92) afirma que "uma das propriedades fundamentais dos modelos mentais é serem pessoalmente únicos e subjetivos" e, desse modo, representarem a maneira como os usuários da língua interpretam ou constroem cada um a seu modo um evento discursivo, com base em objetivos pessoais, conhecimentos ou experiências prévias.

E essas escolhas lexicais compreendem interpretações pessoais que ficam guardadas na memória e pretendem remontar um cenário de um jeito especial e maravilhoso. Especial por ser uma "joia da terra brasileira" (9) e maravilhoso porque "sempre há beleza" (14), além de ser "um bom lugar" (16) e, por isso, reduto de outros bons lugares, como um simples "bar" (17) - com duas ocorrências -, um "bate-papo de café" (18) ou uma "beira-mar" (19) até lugares turísticos, mais conhecidos e, por esse motivo, mais requintados, como o "Cristo Redentor" (23), o "Corcovado" (22) ou o "Pão de Açúcar" (29). Estes locais estão organizados, na tabela, nos numerais de 17 a 32.

Junto ao "Corcovado" (22), há a afirmação de que "da janela vê-se o Corcovado" (24). Paralelamente a essa relação, temos a menção ao bairro de "Santa Tereza" (43) e a asserção de que "quem mora em Santa Tereza/ está pertinho do céu" (72). Por analogia, infere-se nestas duplas de lexias a representação da altura, da altitude e do infinito. Ao expressar a condição de quem mora em Santa Tereza, o enunciador promove uma ligação com o "Cristo Redentor" (23), que fica no "Corcovado" (24), e, portanto, "está pertinho do céu" (72). E a visão da janela supõe uma linha do olhar em direção ao horizonte, subindo ao infinito celeste, ignorando toda e qualquer situação negativa ou problemas terrenos que existam abaixo do Cristo Redentor, entre a janela e o Corcovado.

O discurso constrói uma visão dos locais do Rio como pontos de encontro, de amizade e de boemia e também como abrigo e berço daqueles que ali vivem, visitam ou apenas passam por perto a fim de usufruir, direta ou indiretamente de um determinado espaço. Não obstante, da janela não se 
veem coisas desagradáveis ou problemas sociais, mas sim o "Corcovado" (24), que abriga o "Cristo Redentor" (23) e abençoa toda a "Guanabara" (26).

Problemas sociais, porém, existem e podem ser interpretados por meio da lexia "a vila tem um feitiço sem farofa/ sem vela/ sem vintém/ que nos faz bem" (2) que relata ao enunciatário, num toque de devoção, quão importante é este espaço, já que mesmo diante de dificuldades como a pobreza ou a fome o enunciador prefere se manter no lugar em que está a ter que sair em busca de melhores condições de vida.

Nesse ínterim, salienta-se mais uma vez a lexia "eu caio duro, mas fico em Copacabana" (6), já que o contexto trazido na canção Não vou pra Brasília (1957), é semelhante ao anterior, pois o enunciador declara que "mesmo que seja/ pra ficar cheio da grana/ a vida não se compara/ mesmo difícil, tão cara" ele prefere "cair duro", a deixar Copacabana.

Em seguida, nas lexias de 33 a 44, há referências aos bairros da cidade do Rio de Janeiro. Destaca-se nesse traço semântico o bairro de "Copacabana" (33), com seis ocorrências, além das outras duas que se juntam aos apostos "feiticeira" (34) e "princesinha do mar" (35). O conhecido bairro da Zona Sul carioca, segundo MATOS (2002), era no ano de 1950 centro da vida da então capital federal. Era o bairro mais badalado da cidade, e por ele passava todo tipo de gente: "poetas, políticos, assassinos, estrangeiros e nacionais". Em suas avenidas corriam carros conversíveis, diferentes imagens e sons. Em meio a este cenário, a vida social era originada em diferentes espaços do bairro, de bares até igrejas, de aeroportos até uma "calçada cheia de gente a passar" (20).

Seja em um lugar público, turístico ou em bairros definidos, a relação social, é de alguma forma definida nas lexias - às vezes implícitas, outras vezes explícitas - como em "bar" (17) e "calçada cheia de gente a passar" (20), o que denuncia a possibilidade de pessoas se encontrarem, se conhecerem e se divertirem, o que conduz à ideia da boemia, como característica carioca relevante.

Noel Rosa ilustra muito bem esta vida boêmia, nos botecos da Vila Isabel, onde vivia com os amigos, fumando, conversando e querendo ser reconhecido por todos que ali passavam. "Menino de classe média, até hoje é celebrado como o mais poético e moderno compositor de samba de todos os tempos" (DINIZ, 2006). Cantou o Rio melhor do que ninguém, a começar 
pelo seu lugar de origem, onde nasceu, cresceu e declarou muito amor. Tratase, pois, da própria Vila Isabel (42 e 44).

Porém, a boemia não é exclusividade dos bairros de Copacabana e de Vila Isabel. Sob a mesma égide encontramos, nas lexias entre 37 e 40, destaque para o bairro da Lapa, qualificada pelos compositores como "boêmia" (38), "dos capoeiras" (40) e "vadia" (39).

MÁXIMO (2009, p. 34) reconhece que

a Lapa vem sendo cultuada em música há mais de três quartos de século. Desde os tempos em que era o "bairro do pecado", com seus cabarés iluminados, seus bordéis sombrios, seus cafés cheios, suas farmácias proibidas. Foi, por isso, um bairro muito musical. E continua sendo.

Com a evidência dessas características - boemia e vadiagem - tanto em MÁXIMO (2009) quanto no léxico das canções analisadas, podemos considerar as escolhas lexicais provenientes de modelos mentais relacionados aos espaços localizados no Rio de Janeiro.

Estes modelos podem ser advindos de várias situações de caráter similar àquele que Noel Rosa protagonizava nos botecos. Assim como ele, muitos outros compositores tinham essa prática de frequentar bares e é com base nela que os modelos são concebidos de modo subjetivo e pessoal e passam a constituir um "registro" cognitivo e episódico de experiências individuais e sociais que externam a felicidade por meio da vida noturna.

Como cenário de fundo desses locais públicos, bairros, e tanta devoção há uma convergência para a beleza natural, o ambiente e a paisagem litorânea, como podemos comprovar nas lexias numeradas de 45 a 86 .

Neste subcampo, a lexia campeã é "sol" (79), com sete ocorrências. Não por acaso, ligam-se a ela as lexias que fazem alusão ao verão, estação do ano mais citada nas canções. Prova disso é a própria lexia verão, seguida dos "jardins de sol" (60), "mil verões" (65), "tardes quentes" (82) e "sol a queimar" (80).

E um fator que favorece a construção desse cenário ensolarado na praia é o fato de que esse é um espaço que ganhou importância no final do século XIX, início do século XX, já que LUZ (1994, p. 81) aponta que, nessa época, o banho de mar era indicado apenas como tratamento de saúde e só com o tempo passou a se tornar um hábito social, caracterizando-se como uma opção de lazer ou de esporte para o carioca. SILVA (1999, p. 61) reforça 
que "a concepção que via a praia como lugar de doença dá lugar à ideia de local importante na manutenção dos corpos saudáveis".

Esta concepção une-se também aos nossos primeiros campos semânticos - os quais revelam o "Rio da mulher beleza" (campo 2:7) como sendo aquele que abriga o "corpo dourado" (campo 1:12) e "da pele morena" (campo 1:13). Neste ponto, revela-se, mais uma vez, a presença do "sol", dos "verões", dentro de uma cidade com "tardes quentes" (82), onde o "clima é bem tropical" (53), além de ser "dourado quase todo dia" (56). Além do verão, revela-se uma outra estação do ano nas lexias "cidade de flores" (50) e "jardim florido" (59) - a primavera.

O litoral é representado por lexias como "Rio, teu mar, praias sem fim" (77), "Rio de sol, de céu, de mar" (74), "Rio que mora no mar" (76), "Rio é mar" (75). Nota-se que o Rio é mar, pois a ideia que é transmitida ao interlocutor é que o mar contém o Rio e não o contrário. Assim, é possível admitir que o mar "abraça" a cidade do Rio de Janeiro, transformando-a numa imensidão de água, envolta pelo dia e também pela noite, estas retratadas pelas lexias "noites do Rio ao luar" (68), "meu Rio é lua" (64), "constelado" (55), apenas "lua" (61) ou somente "noite" (67).

Do ponto de vista cognitivo, as escolhas lexicais acima descrevem um modelo mental em que o espaço é o Rio de Janeiro. O verão, o mar e a praia em si são a composição deste espaço, e a noite é o período preferido. Nas canções, a seleção lexical revela modelos de acontecimentos, ou seja, o que os enunciadores pensam sobre a natureza e a relação dela com a "cidade maravilhosa". 


\section{CONSIDERAÇÕES FINAIS}

A análise lexical feita nas canções do corpus revelou o conjunto de valores e crenças que os enunciadores têm sobre a cidade do Rio de Janeiro. A construção do maravilhoso aparece como resultado do processo das escolhas lexicais presentes nas canções desde a chamada Época de Ouro.

Foi nessa época que surgiu a canção "Cidade Maravilhosa", que, internalizada pelos cidadãos cariocas, virou hino da cidade. Apesar de ter sido utilizada pela primeira vez pelo escritor maranhense Coelho Neto, em uma notícia de um jornal datada de 1908, foi em 1934 que a expressão foi nacionalmente consagrada. E a partir de então, as escolhas lexicais mostraram-se voltadas a reforçar a ideia de que o Rio de Janeiro é de fato a cidade maravilhosa.

A principal conclusão deste trabalho refere-se à construção da mulher carioca, expondo sua feminilidade, a pele de cor bronzeada e o amor. A mulher retratada não é frágil, mas também não é forte, é sensual e sabe utilizar esta sensualidade a favor do amor e da atração. É faceira e the agradam os olhares de admiração voltados para ela. Gosta de cuidar, mas também quer ser cuidada; ama, mas também quer ser amada. Usa seu olhar, seu cabelo e suas características faciais para demonstrar seu modo de viver, que é peculiar à mulher vaidosa ou sensual.

O Rio de Janeiro é também retratado como a própria mulher. A feminilidade é transportada à própria cidade, que passa a ser bela, irresistível e inimitável. O amor é um sentimento advindo do mar, do sol, e, também, da própria cidade. Os olhares agora passam a ser para a cidade do Rio de Janeiro, que encanta os olhos de quem a vê e seduz aqueles que por ela passam. Além disso, a felicidade é evidente na "face" da cidade, que "sorri de tudo" e provoca o sorriso das pessoas que para ela sorriem, em uma devolução do sentimento de contentamento e satisfação.

A cidade do Rio, de maneira semelhante à figura da mulher, não pretende ser frágil, mas demonstra uma fortaleza, mostrando-se poderosa por 
meio da capacidade de sedução ou atração, seja ela voltada tanto aos próprios moradores, aos turistas ou mesmo a um simples visitante.

O espaço urbano junto à natureza exige do enunciador uma declaração de que ele gosta da cidade e de que é "eterno se fazer amar"; afinal, a cidade é uma "joia rara" e, como tal, merece um valor descomunal diante do encanto que possui.

Este encantamento revela mais uma vez o poder de sedução que a cidade exerce sobre o enunciador e a figura feminina que nela se confunde, transformando-a na própria mulher, com muitos adjetivos semelhantes que compõem escolhas lexicais relevantes prolongadas até o retrato do espaço urbano carioca.

A cidade do Rio de Janeiro é o espaço urbano que demonstra prestígio e valor social, nem sempre marcados pelo acúmulo de riquezas ou dinheiro, mas pela oportunidade de viver em um local privilegiado por uma riqueza natural, revelada por meio de lexias como "joia da terra brasileira", "cidade do céu sempre azulado" ou "cidade-padrão de beleza”. Cria-se a imagem de uma natureza que, de tão perfeita, é motivo de orgulho para o enunciador, que chega a ser um devoto do Rio de Janeiro.

Locais turísticos e bairros da cidade também são mencionados nas letras das canções, é o caso do bairro da Lapa, marcado por boemia, vadiagem e capoeira e, portanto, alusivo à diversão, à boa-vida e à vida despreocupada de alguém que neste espaço nasceu, cresceu e deseja morrer.

Copacabana é a "princesinha do mar" e a "feiticeira da cidade", o que Ihe confere certo ar de encantamento, mistério e atração. Torna-se soberana e traz para a cidade um tom de "conto de fadas". O Rio passa a ser um castelo que abriga a linda princesa - Copacabana - onde é possível se criar feliz e viver nesta condição para sempre.

Além da princesa há a Vila Isabel, lembrada por seu "nome de princesa" e que faz referência histórica à Lei Áurea, decisão que tinha por finalidade libertar os escravos dos senhores de engenho e da elite cafeeira. Assinada pela Princesa Isabel, o bairro carioca é intimamente ligado a esta história e dialoga por meio dela com a democracia racial.

Qualifica-se a cidade do Rio de Janeiro como o local que aceita e convive bem com pessoas de diferentes culturas, etnias e classes sociais. Há 
a presença de vários gêneros musicais e a alusão do Rio de Janeiro como o "berço do samba", gênero musical da alegria, que reuniu diferentes pessoas em um mesmo espaço. É uma cidade que canta e que é a própria música.

Seja cantar, sambar ou dançar, tudo se faz "alegremente" e infere-se que o "batuque", a "batucada" e todas as derivações dessas lexias contribuam com a beleza e com a razão de o Rio de Janeiro ser considerado sempre o "primeiro num samba-canção".

Com isso, completa-se um espaço urbano que incorpora locais públicos, bairros e paisagem natural à musicalidade tanto do vento e das ondas do mar quanto da batucada e do samba. Ignoram-se questões urbanas relacionadas à higiene ou à estética, pois todo espaço parece ser digno de beleza e sofisticação - como até mesmo a natureza, sustentada por um "bom clima tropical".

Cria-se também a imagem de uma cidade romântica, que tem amor, carinho e noites do Rio ao luar. Nesse ponto, o Rio também se descortina como sendo o próprio romantismo ou a própria iluminação em uma noite escura, já que há uma lexia que afirma ser o Rio a própria Lua - símbolo dos casais apaixonados e ícone da iluminação noturna.

Analisar a cidade maravilhosa, a partir do léxico, é perceber como as unidades lexicais são atualizadas no discurso por meio de uma interface cognitiva e reconhecer o conhecimento partilhado que se revela na constituição de sentidos, que são revelados por meio das palavrastestemunha.

Percorrê-las é caracterizar a cidade, cotidianamente, em dias ensolarados e noites enluaradas em que mulheres desfilam pelas ruas, praias e avenidas, incorporadas à paisagem ímpar e deslumbrante do Rio de Janeiro. Os homens, por sua vez, praticam a boemia, apreciam a beleza feminina e reverenciam a cidade maravilhosa por ser a dona de tamanho esplendor.

Cada lexia e campo semântico não podem ser vistos como unidades individuais e sim como partes de um todo integrado, já que a mulher carioca que vive no espaço urbano, pode se misturar à própria cidade que, por si só, traz a alegria de reunir várias etnias.

Há uma estreita relação entre o discurso das canções, a ideologia e as práticas relativas à sociedade carioca. Numa abordagem linguística, mais 
contemporânea, a ideologia de que o Rio de Janeiro é a cidade maravilhosa pode ser descrita a partir de axiomas que são compartilhados por grupos e, amplamente, reproduzidos pelo texto e discurso. Esses axiomas são representados pelas palavras-testemunhas.

Por isso se entende que as canções materializam linguisticamente escolhas operadas nos contextos não só cariocas, mas também nacionais. Ao interagir pela linguagem e ouvir canções que retratam a cidade maravilhosa, as pessoas estão automaticamente engajadas no processamento do discurso e na construção dinâmica de análise e interpretação do léxico.

Mais tarde, ao elegerem uma ou outra lexia referente à beleza, ao balanço ou ao encanto que a cidade do Rio de Janeiro possui, elas estarão controladas por modelos mentais, que são as representações cognitivas das experiências de cada indivíduo.

Analisar, criticamente, um grupo social que com sua prática profissional de compor canções possibilitou a visão dessa "cidade-mulher" foi o desafio constante desta pesquisa, na qual revelam-se, enfim, quatro palavrastestemunha: "A mulher no Rio de Janeiro", "Rio de Janeiro é mulher", "Rio de Janeiro é música" e "Rio de Janeiro é espaço urbano". Em torno destas palavras criaram-se esferas conceituais que são compartilhadas pelos enunciadores e que fazem a cidade do Rio de Janeiro ser maravilhosa por conter um espaço urbano composto pela mulher linda, feminina e amável; pela música, que representa alegria, união e entretenimento; pelo lugar marcado pela natureza e por diversos locais interessantes. Vê-se a cidade do Rio de Janeiro como a própria mulher, com curvas naturais (compostas pela paisagem natural) e uma bela "face" (percebida pela personificação da cidade), onde moram pessoas sempre felizes, divertidas e das mais diversas etnias. 


\section{REFERÊNCIAS}

BARROSO, Ary. Rio. In: [online] Disponível na Internet via < http://www.letras.com.br/\#!ary-barroso/rio >. Acessado em 2/5/2013.

BATISTA, Wilson e MARTINS, Roberto. Pertinho do céu. In: [online] Disponível na Internet via <http://www.sambaderaiz.net/o-samba-carioca-dewilson-baptista/>. Acessado em 5/5/2013.

BATISTA, Wilson e PINTO, Marino. Largo da Lapa. In: [online] Disponível na Internet via <http://www.sambaderaiz.net/o-samba-carioca-de-wilsonbaptista/>. Acessado em 5/5/2013.

BATISTA, Wilson e Castro, Jorge de. História da Lapa. In: [online] Disponível na Internet via <http://www.sambaderaiz.net/o-samba-carioca-de-wilsonbaptista/>. Acessado em 5/5/2013.

BIDERMAN, Maria Tereza Camargo. Teoria linguística: teoria lexical e linguística computacional. 2 ed. - SP: Martins Fontes, 2001.

BORBA, Francisco da Silva. Organização de dicionários: uma introdução à lexicografia. SP: Editora UNESP, 2003.

BÔSCOLI, Ronaldo. Rio. In: [online] Disponível na Internet via $<$ http://services.radio.uol.com.br/\#/letras-e-musicas/ronaldoboscoli//rio/1794689>. Acessado em 15/3/2012.

BÔSCOLI, Ronaldo e MESNESCAL, Roberto. Rio 1800. In: [online] Disponível na Internet via < http://www.radio.uol.com.br/\#/letras-e-musicas/oscariocas/rio-1800/2211343>. Acessado em 15/3/2012.

CABRAL, Sérgio. Elas contam tudo. In MOUTINHO, Marcelo (org.). Canções do Rio: a cidade em letra e música. 45-54. Rio de Janeiro: Casa da Palavra, 2009.

CARVALHO, José Murilo de. Os bestializados: o Rio de Janeiro e a república que não foi. SP: Cia. Das Letras, 1987

CASTRO, Ruy. Chega de saudade: a história e as histórias da Bossa Nova. SP: Companhia das Letras, 2008.

CAYMMI, Dorival e GUINLE, Carlos. Sábado em Copacabana. In: [online] Disponível na Internet via http://www.bossanova.mus.br/conteudo/musicas/sabadoemcopacab ana.htm>. Acessado em 5/5/2013.

DINIZ, André. Almanaque do Samba. RJ: Jorge Zahar Ed., 2006.

FILHO, André. Cidade Maravilhosa. In: No olho da rua: ele é carioca (CD). Brasil: Ethos, 2007

FREYRE, Gilberto. Casa-grande \& senzala: formação da família brasileira sob o regime da economia patriarcal. 481 ed. rev. - São Paulo : Global, 2003.

GIL, Beatriz Daruj. A mulher no léxico da canção de consumo: um discurso polarizado. In MELO, Iran Ferreiro de (org.). Introdução aos estudos críticos 
do discurso: teoria e prática. 189-202. Campinas, São Paulo: Pontes Editores, 2012.

HENRIQUES, Claudio Cezar. Léxico e semântica: estudos produtivos sobre palavra e significação. Rio de Janeiro: Elsevier, 2011

Instituto Memória Musical Brasileira (IMMUB). Disponível em http://www.memoriamusical.com.br/. Acesso em 12/1/2014

JOBIM, Tom. Copacabana. In: [online] Disponível na Internet via $<$ http://www.radio.uol.com.br/\#/letras-e-musicas/tomjobim/copacabana/883315>. Acessado em 10/3/2012.

JOBIM, Tom. Corcovado. In: [online] Disponível na Internet via <http://www2.uol.com.br/tomjobim/ml_corcovado.htm>. Acessado em 10/3/2012.

JOBIM, Tom. Ela é carioca. In: [online] Disponível na Internet via < http://www2.uol.com.br/tomjobim/ml_ela_e_carioca.htm>. Acessado em $10 / 3 / 2012$.

JOBIM, Tom e MORAES, Vinícius de. Garota de Ipanema. In: [online] Disponível na Internet via < http://www2.uol.com.br/tomjobim/ml_garota_de_ipanema.htm>. Acessado em 10/3/2012.

JOBIM, Tom e MORAES, Vinícius de. O morro não tem vez. In: [online] Disponível na Internet via < http://www2.uol.com.br/tomjobim/ml_o_morro_nao_tem_vez.htm>. Acessado em 10/3/2012.

JOBIM, Tom. Samba do avião. In: [online] Disponível na Internet via < http://www2.uol.com.br/tomjobim/ml_samba_do_aviao.htm>. Acessado em 2/3/2012.

JOBIM, Tom e BLANCO, Billy. Tereza da Praia. In: [online] Disponível na Internet via <http://www2.uol.com.br/tomjobim/ml_tereza_da_praia.htm>. Acessado em 2/3/2012.

LOPES, Nei. Cidade, quem te fala é um sambista. In MOUTINHO, Marcelo (org.). Canções do Rio: a cidade em letra e música. 25-41. Rio de Janeiro: Casa da Palavra, 2009.

LÖWI, Michael. Ideologias e Ciência Social: elementos para uma análise marxista. SP: Cortez, 2008

LUZ, Madel. "O corpo da cidade". In Pechman, Robert Moses (org). Olhares sobre a cidade. RJ, UFRJ, 1994

MACHADO NETO, Diósnio . O "mulatismo musical" processos de canonização na historiografia musical brasileira. In: Maria do Rosário Girão Santos; Elisa Maria Lessa. (Org.). Música, Discurso e Poder. 1 ed. Vila Nova de Famalicão: Humus / Universidade

do Minho, 2012 .Disponível em <https://www.academia.edu/2921511/O_mulatismo_ 
musical_os_processos_de_canonizacoes_na_historiografia_musical_brasilei ra>. Acesso em 10/6/2014

MATOS, Maria Izilda de. Dolores Duran: Experiências Boêmias em Copacabana nos anos 50. Rio de Janeiro: Bertrand Brasil, 2.ed, 2002

MÁXIMO, João. A cabocla de caxangá sob o luar de Paquetá. In MOUTINHO, Marcelo (org.). Canções do Rio: a cidade em letra e música. 25-41. Rio de Janeiro: Casa da Palavra, 2009.

MORAES, Vinícius de. Mulher carioca. In: [online] Disponível na Internet via < http://www.radio.uol.com.br/\#/letras-e-musicas/vinicius-de-moraes/mulhercarioca/ 976557>. Acessado em 10/3/2012.

MORAES, Vinícius de e LYRA, Carlos. Samba do carioca. In: [online] Disponível na Internet via <http://www.radio.uol.com.br/\#/letras-emusicas/quarteto-em-cy-e-vinicius/samba-do-carioca/432638>. Acessado em 2/3/2012.

MOUTINHO, Marcelo (org.). Canções do Rio: a cidade em letra e música. Rio de Janeiro: Casa da Palavra, 2009.

NAPOLITANO, Marcos. História \& Música. História cultural da música popular. BH: Autêntica, 2002.

NETTO, Ismael e MARIA, Antônio. Valsa de uma cidade. In: [online] Disponível na Internet via <http://www.radio.uol.com.br/\#/letras-emusicas/miucha/valsa-de-uma-cidade/1103575>. Acessado em 10/05/2013.

NUNES, José Horta. Lexicologia e Lexicografia in GUIMARÃES, Eduardo e FONTANA, Mônica Zoppi (orgs). A palavra e a frase - Campinas, SP: Pontes Editores, 2006.

POTTIER, Bernard. Linguística Geral: teoria e descrição. RJ: Universidade Santa Úrsula, 1978.

RIDENTI, Marcelo. Em busca do povo brasileiro -artistas da revolução, do CPC à era da TV. Rio de Janeiro: Record, 2000

ROSA, Noel. Cidade mulher. In: [online] Disponível na Internet via < http://www.letras.com.br/\#!noel-rosa/cidade-mulher>. Acessado em 12/05/2013.

ROSA, Noel. Feitiço da Vila. In: [online] Disponível na Internet via <http://www.mpbnet.com.br/musicos/noel.rosa/letras/feitico_da_vila.htm>.

Acessado em 10/05/2013.

SILVA, Lúcia. A cidade do Rio de Janeiro nos anos 20: urbanização e vida urbana in FENELON, Déa Ribeiro (org.). Cidades. P. 55-84 São Paulo: Olho D'água e PUC-SP, 1999

TATIT, Luiz Augusto de Moraes. O cancionista: composição de canções no Brasil. 2ed. São Paulo: Editora da Universidade de São Paulo, 2002 
O Século da Canção. Cotia: Ateliê Editorial, 2004

TINHORÃO, José Ramos. Música popular: um tema em debate. São Paulo: Ed. 34, 1997.

TRIGUEIRO, Nelson e BELANDI, Oscar. Meu Rio de Janeiro. In: [online] Disponível na Internet via < http://services.radio.uol.com.br/\#/letras-emusicas/dick-farney/meu-rio-de-janeiro/319881 >. Acessado em 12/5/2013.

ULLMANN, Stephen. Semântica: uma introdução à ciência do significado. Lisboa: Fundação Calouste Gulbenkian, 1964.

VAN DIJK, Teun Adrianus. Cognição discurso e interação. São Paulo: Contexto, 2004

. Discurso, cognición y sociedade. Rev. Signos, Valparaíso, v. 22, out-dez de 1997. p. 66-74. Disponível em <http://www.discursos.org/oldarticles/Discurso\% 20cognicion\%20y\%20sociedad.pdf>. Acesso em 15 agosto 2013. Contexto, 2012.

. Discurso e contexto: uma abordagem sociocognitiva. São Paulo:

La multidisciplinaridad del análisis crítico del discurso: um alegato em favor de la diversidade. Campinas, São Paulo: Pontes Editores, 2003.

Política, Ideologia e Discurso. In MELO, Iran Ferreiro de (org.). Introdução aos estudos críticos do discurso: teoria e prática. 15-51. Campinas, São Paulo: Pontes Editores, 2012.

VILELA, Mário. Estudos de lexicologia do Português. Coimbra: Livraria Almedina, 1994.

Estruturas léxicas do Português. Coimbra: Livraria Almedina, 
Anexo 1: Letras das canções analisadas

Cidade Maravilhosa

COMPOSITOR: ANDRÉ FILHO

1934

Refrão:

Cidade maravilhosa, cheia de encantos mil

Cidade maravilhosa, coração do meu Brasil!

Berço do samba e das lindas canções,

que vivem n'alma da gente. Es o altar dos nossos corações que cantam alegremente!

Jardim florido de amor e saudade, terra que a todos seduz.

Que Deus te cubra de felicidade, ninho de sonho e de luz!
FEITIÇO DA VILA

COMPOSITOR: NOEL ROSA

1934

Quem nasce lá na Vila

Nem sequer vacila

Ao abraçar o samba

Que faz dançar os galhos, Do arvoredo e faz a lua, Nascer mais cedo.

Lá, em Vila Isabel, Quem é bacharel

Não tem medo de bamba.

São Paulo dá café, Minas dá leite,

E a Vila Isabel dá samba.

A vila tem um feitiço sem farofa Sem vela e sem vintém

Que nos faz bem

Tendo nome de princesa

Transformou o samba

Num feitiço descente

Que prende a gente

O sol da Vila é triste

Samba não assiste

Porque a gente implora:

"Sol, pelo amor de Deus,

não vem agora

que as morenas

vão logo embora

Eu sei tudo o que faço

sei por onde passo

paixao nao me aniquila

Mas, tenho que dizer, modéstia à parte, meus senhores,

Eu sou da Vila! 
Cidade Mulher

COMPOSITOR: NOEL ROSA

1936

Cidade de amor e aventura

Que tem mais doçura

Que uma ilusão

Cidade mais bela que o sorriso, Maior que o paraíso

Melhor que a tentação

Cidade que ninguém resiste

$\mathrm{Na}$ beleza triste

De um samba-canção

Cidade de flores sem abrolhos

Que encantando nossos olhos

Prende o nosso coração

Cidade notável,

Inimitável,

Maior e mais bela que outra

qualquer.

Cidade sensível,

Irresistível,

Cidade do amor, cidade mulher.

Cidade de sonho e grandeza

Que guarda riqueza

$\mathrm{Na}$ terra e no mar

Cidade do céu sempre azulado,

Teu Sol é namorado

Da noite de luar

Cidade padrão de beleza,

Foi a natureza

Quem te protegeu

Cidade de amores sem pecado, Foi juntinho ao Corcovado

Que Jesus Cristo nasceu
Pertinhodo Céu

COMPOSTIORES: WILSON BATISTAE

ROBERTO MARTINS

1941

Eu moro no morro que não tem batucada.

Não tem barracão mas tem rua bem calçada.

O clima é bom e o lugar é uma beleza.

Eu moro no morro de Santa

Teresa.

Não tem pandeiro, nem camisa de malandro

Não tem cabrocha faceira, De tamanco na ladeira.

Mas tem morenas e louras

Que são o nosso troféu.

Quem mora em Santa Teresa

Está pertinho do céu. 
LARGO DA LAPA

COMPOSITORES: WILSON BATISTA E MARINO PINTO

1942

Foi na Lapa que eu nasci,

Foi na Lapa que eu aprendi a ler,

Foi na Lapa que eu cresci,

E na Lapa, eu quero morrer.

A Lapa também tem a sua igreja, Pra que toda gente veja,

Onde eu fui batizado,

A Lapa, onde já não há conflito,

Fica no $5^{\circ}$ Distrito,

Aonde eu fui criado,

Um samba, um sorriso de mulher, Bate-papo de café,

Eis aí a Lapa,

Um samba, um sorriso de mulher, Bate-papo de café,

Eis aí a Lapa.

Foi na Lapa que eu nasci...

\section{Rio}

Compositor: ARy Barroso

1948

Rio,

Barulho de rodas rangendo

Barulho de gente correndo

Que vai pro trabalho e é feliz

Rio

Batida de bombo e pandeiro

Batuque do bom no terreiro

Cabrochas gingando seus quadris

Rio

Que conta anedota no bar

Que vai pros estádios gritar

Canta samba de improviso

Rio

Copacabana feiticeira

Jóia da terra brasileira

Pedaço do paraíso

Bate tamborim

Oi, baticum lelê

Rio de Janeiro

Rio, Rio

Céu azul

Verdes montanhas

E o mar de águas verdes

Praias inundadas de sol

Pra laiá, laiá

Pra loiô, loiô

Pra Sinhá, sinhá

E pra Sinhô

Terra de amor

De luz

De vida

E de resplendor 
MEu Rio de JANEIRO

Compositor: NeLSON TRIGUEIRO E OSCAR BELANDI

1948

Meu Rio de Janeiro

Rio, tu és de janeiro e do ano

inteiro, quem há de negar?

Praias, tens Copacabana

Que toda semana convida a nadar

Teu clima é bem tropical

E o teu carnaval é uma

consagração

Rio tu és de janeiro

E és sempre o primeiro num samba-canção.

A llha de Paquetá é uma joia rara em tua Guanabara

Pão de Açúcar, Corcovado, teu céu tão lindo constelado

Deus me fez brasileiro, e eu me sinto feliz

Desafio quem prove o contrário Nestas palavras que o meu samba diz.

\section{SÁBADO EM CopACABANA \\ COMPOSITOR: DORIVAL CAYMMI E Carlos GuinLe 1951}

Depois de trabalhar toda semana Meu sábado não vou desperdiçar Já fiz o meu programa para esta $n$ oite

E já sei por onde começar.

Um bom lugar pra encontrar Copacabana

Pra passear á beira mar

Copacabana

Depois um bar, á meia luz

Copacabana

Eu esperei por esta noite uma semana

Um bom jantar, depois dançar Copacabana

Pra se amar, um só lugar

Copacabana

E a noite passa

Tão depressa

Mas vou voltar lá prá semana

Se eu encontrar um novo amor

Copacabana 
VALSA DE UMA CidAdE

COMPOSITOR: ISMAEL NETTO E

ANTÔNIO MARIA

1954

Vento do mar no meu rosto

E o sol a queimar,queimar,

Calçada cheia de gente, a passar

E a me ver passar,

Rio de Janeiro,gosto de você,

Gosto de quem gosta

Deste céu,deste sol,

Dessa gente feliz.

Bem que eu quis

Escrever um poema de amor,

E o amor,estava em tudo que eu vi

Em tudo quanto eu amei

E no poema que eu fiz

Tinha alguém mais feliz que eu, O meu amor,que não me quis!
Tereza da Praia

COMPOSITOR: TOM JOBIM E BILLY

BLANCO

1954

Lúcio arranjei novo amor no

[Leblon

Que corpo bonito,que pele morena

Que amor de pequena, amar é tão

[bom!

O Dick! Ela tem um nariz levantado os olhos verdinhos bastante

[puxados

cabelo castanho e uma pinta do

[lado

É a minha Tereza da praia

Se é tua é minha também

O verão passou todo comigo

$\mathrm{O}$ inverno pergunta com quem

Então vamos a Tereza na praia

[deixar

Aos beijos do sol e abraços do mar

Tereza é da praia,

não é de ninguém

não pode ser tua ...

nem minha também

Tereza é da praia

Não é de ninguém 
Copacabana

COMPOSITOR: TOM JOBIM

1954

Existem praias tão lindas,

cheias de luz

Nenhuma tem o encanto que tu possuis

Tuas areias

Teu céu tão lindo

Tuas sereias

Sempre sorrindo.

Copacabana, princesinha do mar Pelas manhãs tu és a vida a cantar E a tardinha, o sol poente Deixa sempre uma saudade Na gente.

Copacabana, o mar eterno cantor Ao te beijar ficou perdido de amor $E$ hoje vivo a murmurar

Só a ti Copacabana

Eu hei de amar.
Não Vou Pra Brasília

COMPOSITOR: BILLY BLANCO 1957

Eu não sou índio nem nada Não tenho orelha furada

Nem uso argola

Pendurada no nariz

Não uso tanga de pena $E$ a minha pele é morena Do sol da praia onde nasci E me criei feliz

Não vou, não vou pra Brasília Nem eu nem minha família Mesmo que seja

Pra ficar cheio da grana

A vida não se compara Mesmo difícil, tão cara Eu caio duro Mas fico em Copacabana 
HISTÓRIA DA LAPA

COMPOSITOR: WILSON BATISTA E JORGE DE CASTRO

1957

Lapa, dos capoeiras,

Miguelzinho camisa preta,

Meia Noite e Edgar,

Lapa, minha Lapa boêmia,

A lua só vai pra casa,

Depois do sol raiar.

Falta uma torre na igreja,

Vou lhe contar, meu irmão,

Foi na briga de Floriano,

Foi um tiro de canhão,

E nesse dia a Lapa vadia,

Teve sua gloria,

Deixou seu nome na história.
Corcovado

COMPOSITOR: TOM JOBIM

1960

Um cantinho e um violão

Esse amor, uma canção

Pra fazer feliz a quem se ama

Muita calma pra pensar

E ter tempo pra sonhar

Da janela vê-se o Corcovado

O Redentor que lindo

Quero a vida sempre assim com você perto de mim

Até o apagar da velha chama

E eu que era triste

Descrente deste mundo

Ao encontrar você eu conheci

$\mathrm{O}$ que é felicidade, meu amor 
SAMBA do Avião

COMPOSITOR: TOM JOBIM

1962

Minha alma canta,

Vejo o Rio de Janeiro,

Estou morrendo de saudade.

Rio, teu mar, praias sem fim,

Rio, você foi feito pra mim.

Cristo Redentor, Braços abertos sobre a Guanabara.

Este samba é só porque, Rio, eu gosto de você,

A morena vai sambar, seu corpo todo balançar.

Rio de sol, de céu, de mar, Dentro de mais um minuto estaremos no Galeão

Aperte o cinto, vamos chegar, Água brilhando, olha a pista chegando,

E vamos nós.

Pousar
Eláé Carioca

COMPOSITOR: TOM JOBIM

1962

Ela é carioca

Ela é carioca

Basta o jeitinho dela andar

Nem ninguém tem carinho assim para dar

Eu vejo na luz dos seus olhos

As noites do Rio ao luar

Vejo a mesma luz

Vejo o mesmo céu

Vejo o mesmo mar

Ela é meu amor, só me vê a mim A mim que vivi para encontrar

Na luz do seu olhar

A paz que sonhei

Só sei que sou louco por ela

E pra mim ela é linda demais

$E$ além do mais

Ela é carioca

Ela é carioca 
O Morro Não Tem Vez

COMPOSITORES: TOM JOBIM E ViníCIUS DE MORAES

1962

O morro não tem vez

E o que ele fez já foi demais

Mas olhem bem vocês

Quando derem vez ao morro

Toda a cidade vai cantar

Morro pede passagem

O morro que se mostrar

Abram alas pro morro

Tamborim vai falar

É 1, é 2, é 3, é 100

É 1000 a batucar

O morro não tem vez

Mas se derem vez ao morro

Toda cidade vai cantar
Rio

Compositor: Ronaldo Bôscoli 1963

Rio que mora no mar

sorrio pro meu Rio

que tem no seu mar

lindas flores que nascem morenas

em jardins de sol

Rio, serras de veludo

sorrio pro meu Rio que sorri de tudo

que é dourado quase todo dia

e alegre como a luz

Rio é mar

eterno se fazer amar

o meu Rio é lua

amiga branca e nua

É sol, é sal, é sul

são mãos se descobrindo

em tanto azul

por isso é que meu Rio

da mulher beleza

acaba num instante

com qualquer tristeza

meu Rio que não dorme

porque não se cansa

meu Rio que balança

Sorrio, só Rio, só Rio... 
Mulher Carioca

COMPOSITOR: VINICIUS DE MORAES 1963

Ela tem um jeitinho como ninguém Que ninguém tem

A gaúcha tem a fibra A mineira o encanto tem A baiana quando vibra Tem tudo isso e o céu também

A capixaba bonita É de dar água na boca E a linda pernambucana $\mathrm{Ai}$, meu Deus, que coisa louca!

A mulher amazonense Quando é boa é demais Mas a bela cearense Não fica nada para trás

A paulista tem a "erva" Além das graças que tem A nordestina conserva Toda a vida e o querer-bem

A mulher carioca

O que é que ela tem?

Ela tem tanta coisa

Que nem sabe que tem

Ela tem o bem que tem Tem o bem que tem o bem Tem o bem que ela tem Que ninguém tem, que tem

Ela tem um pouquinho que ninguém tem

Ela faz um carinho como ninguém Ela tem um passinho que vai e que vem

Ela tem um jeitinho de nhemnhem-nhem

A carioca tem um jeitinho de nhem-nhem-nhem

Tem um jeitinho de nhem-nhemnhem

Tem um carinho também

A carioca faz um passinho de nhem-nhem-nhem

\section{GAROTA DE IPANEMA \\ COMPOSITORES: TOM JOBIM E \\ ViníCIUS DE MORAES \\ 1963}

Olha que coisa mais linda

Mais cheia de graça

É ela menina

Que vem e que passa

Num doce balanço

A caminho do mar

Moça do corpo dourado

Do sol de lpanema

O seu balançado é mais que um poema

É a coisa mais linda que eu já vi passar

Ah, por que estou tão sozinho?

Ah, por que tudo é tão triste?

$A h$, a beleza que existe

A beleza que não é só minha

Que também passa sozinha

Ah, se ela soubesse

Que quando ela passa

O mundo inteirinho se enche de

graça

E fica mais lindo

Por causa do amor 
SAMBA DO CARIOCA

COMPOSITOR: VINICIUS DE MORAES E

Carlos LyRa

1964

Vamos, carioca

Sai do teu sono devagar

O dia já vem vindo aí

O sol já vai raiar

São Jorge, teu padrinho

Te dê cana pra tomar

Xangô, teu pai, te dê

Muitas mulheres para amar

Vai o teu caminho

É tanto carinho para dar

Cuidando do teu benzinho

Que também vai te cuidar

Mas sempre morandinho

Em quem não tem com quem

morar

Na base do sozinho não dá pé

Nunca vai dar

Vamos, minha gente

É hora da gente trabalhar

O dia já vem vindo aí

O sol já vai raiar

E a vida está contente

De poder continuar

E o tempo vai passando

Sem vontade de passar

$\hat{E}$, vida tão boa

Só coisa boa pra pensar

Sem ter que pagar nada

Céu e terra, sol e mar

$E$ ainda ter mulher

De ter o samba pra cantar

O samba que é o balanço

Da mulher que sabe amar
Rio 1800

Compositores: Roberto

Menescal e Ronaldo Bôscoli

1965

Rio

Deu bênção e vida,

Manha cumprida

De mil verões.

Rio

No ar brilhando

E o rio amando,

Rio...

$E$ as serestas lindas de balcão

$E$ as serestas lindas que virão.

Canta, canta rio

Das tardes quentes,

Da gente indo e voltando,

Sempre voltando nas praças de

luz.

Tíbias, vestidas de cor

E tanto amor,

Fazendo o rio assim.

E sempre há beleza,

Nunca há tristeza.

Rio

De luzes tantas,

Morenas quantas,

Es meu assim.

Que praias bonitas e mar,

E a bossa que faz temperado do céu,

Sorrindo de luz.

Bem, mulher bonita assim, carioca assim,

Rio

Que tanta vida deu,

Meu rio,

És meu rio,

Mas meu rio é meu. 